\title{
Mathews, Gynther and Chambers: three pioneering Australian theorists
}

\author{
Geoffrey Whittington and Stephen A. Zeff*
}

\begin{abstract}
This paper reviews the professional careers and contributions of three distinguished Australian academics, Russell Mathews, Reg Gynther and Ray Chambers, each of whom died recently. Particular attention is paid to their contributions to the debate on price change accounting, including the exchanges that took place between them on this subject. Price change accounting was a central issue in academic and professional debates of the $1960 \mathrm{~s}$ and $1970 \mathrm{~s}$, when the trio were at the peak of their activity as academics. The paper also records the wide range of their contributions to accounting research, education, standard setting and public policy.
\end{abstract}

\section{Introduction}

Three pioneering Australian accounting theorists recently passed from the scene: Russell Mathews, Reg Gynther and Ray Chambers. Another Australian pioneer, Lou Goldberg, a noted historian and theorist, died in 1997.' All four made substantial marks not only in Australia but also overseas. The purpose of this article is to recognise the respective contributions to the accounting discipline of Mathews, Gynther and Chambers, who died between September 1999 and March 2000.

Mathews, Gynther and Chambers, together with Goldberg, while distinctive figures in the postwar evolution of accounting academe in Australia, nonetheless had a number of attributes and achievements in common: they were intellectual leaders par excellence, they were the first four presidents of the organisation of Australian accounting educators, and they were the first fulltime accounting academics at their respective universities. Ray Ball has written that 'these people established the honors and doctoral programs that captured the interest of and trained my generation. Without them I wouldn't be here'?

In addition to their important work in developing accounting as an academic discipline in universities, the trio also made important contributions to

* The authors appreciate the major assistance, including comments on an early draft of parts 1 and 2, supplied by Ken Wright, Frank Finn, Allan Barton and Geoff Burrows, as well as the useful comments by others who read early drafts: John McB. Grant, Scott Henderson, Philip Brown, Ray Ball, Kevin Stevenson, Richard Morris, Graeme Dean, George Foster, Michael Gaffikin, Jayne Godfrey, Lee Parker, Allen Craswell, Stewart Leech, Bob Officer, Jean Kerr, Merle Gynther and Geoff Harcourt. They also appreciate the information furnished by Russell Craig. Malcolm Miller, Jill Bright and Graham Peirson, and interviews with Allan Barton and Geoff Harcourt. The comments from an anonymous referee were useful. The authors are solely responsible for what remains. the development of accounting thought. In particular, they were all involved in the fierce international debate on price change accounting which raged in the 1960s and 1970s, and we shall use their contributions to this debate to illustrate their different styles of thought and the interactions between them.

The paper proceeds as follows. First, we describe the historical context within which our trio worked. Second, we provide biographical sketches of each, particularly emphasising their contribution to accounting thought and education. Third, we discuss the distinctive contributions of each to the price change accounting debate. Fourth, we examine two controversial exchanges between Chambers and Mathews and between Chambers and Gynther. Finally, we consider the legacy of the trio from the perspective of the present day.

\section{Historical context}

The era of predominantly full-time accounting academics both in Great Britain and Australia dawned after World War II, lagging the Americans by some four decades. The first full-time accounting chairs in Britain were filled in 1947 (by William T. Baxter at the London School of Economics (LSE), and Donald Cousins at the University of Birmingham ${ }^{3}$ ), but in Australia it was not until 1955 that the first full-time accounting professor, E. Bryan Smyth, at the University of New South Wales, commenced his tenure. ${ }^{4}$ Four years later, Louis Goldberg became the second full-time ac-

\footnotetext{
${ }^{1}$ For personal portraits of Goldberg, including a list of his publications, see Kerr and Clift (1989) and Parker (1994).

${ }^{2}$ Letter from Ball to Zeff, dated 20 July 2000.

${ }^{3}$ For further discussion, see Zeff (1997: 9).

In this paper, the year in which a chair's occupant began his tenure, not the year in which the appointment was made, is used throughout.
} 
counting professor in Australia, filling the G. L Wood chair at the University of Melbourne. ${ }^{5}$ Goldberg thus succeeded the distinguished practitioner, scholar and public servant, Sir Alexander Fitzgerald, who had occupied the chair on a parttime basis since its inception in 1954 and had served as a part-time lecturer in the university continuously since 1925 . In 1958, Mathews had become professor of commerce at the University of Adelaide. In the 1960s, Australian universities continued to stimulate academic work in accounting, installing eight foundation professorships in, or related to, accounting, as follows:

1960 Ray Chambers, University of Sydney

1960 John McB. Grant, University of Tasmania, professor of applied economics (with special reference to accounting)

1965 James W. Bennett, Monash University

1965 Mathews, Australian National University, professor of accounting and public finance; F. Kenneth Wright succeeded to Mathews' Adelaide chair

1966 Martin O. Jager, Newcastle University

1967 Reg Gynther, University of Queensland

1967 Allan D. Barton, Macquarie University

1968 Athol S. Carrington, University of New South Wales

In Britain and Australia, the accounting theory literature began to build in the 1930s. In Britain, Ronald S. Edwards (1938) and R. H. Coase (1938) wrote important articles, and they were succeeded in the literature by William T. Baxter, Harold Edey and David Solomons following the war (see Whittington, 1994) ${ }^{6}$ These early theorists were all at LSE, and LSE graduates of the 1950s and 1960 s, as well as a growing cadre of researchers from other institutions, continued to make important contributions (see Whittington, 1981).

Australian accounting theorists also launched their efforts in the 1930s, when Fitzgerald began writing a stream of articles that culminated in the publication of two books in 1952: Current Accounting Trends and, with L. A. Schumer, Classification in Accounting. ${ }^{7}$ Through his many articles, his public lectures, and his leadership in the professional accountancy bodies, Fitzgerald stimulated interest in academic and professional accounting developments that were occurring in the US and the UK, including especially the growing literature on accounting theory. As Sir Douglas Copland has written, 'no other person has contributed so much and in so many capacities to the academic development of accounting [in Australia] as Sir Alexander Fitzgerald' (1965: Introduction). Although the chair that Fitzgerald occupied for five years in the 1950s was part-time, he was believed to have spent more time at the university than many full-time academics. ${ }^{8}$
In 1939, Louis Goldberg began his many contributions with the publication of his landmark thesis, A Philosophy of Accounting. By the 1950s, Australian accounting theorists began to develop an even more vibrant literature. At Sydney and Adelaide, Chambers and Mathews (with Grant), respectively, were beginning to mark out significant theoretical turf. And in the 1960s, Gynther, at Queensland, began to stake his own claim. Kenneth Wright and others joined in the quest.

It is interesting that a country as small as Australia has produced so many important contributors to the international literature on accounting theory. One view on this phenomenon is that of Ken Wright: 'I believe that an important source of that strength was the fact that all our university departments of accounting were located in faculties of economics'. 9

Publication outlets for theory papers were comparatively few until the 1960s: the professional magazines The Accountant and the Incorporated Accountants' Journal (which became Accountancy in 1938) in Britain, The Australian Accountant, and The Journal of Accountancy in the US, plus the two academic journals The Accounting Review and Accounting Research (1948-1958). In the 1960s, the Journal of Accounting Research, The International Journal of Accounting Education and Research, and Chamber's' ambitious entrant, Abacus, quickly became established vehicles.

\section{Biographies}

\subsection{Russell Lloyd Mathews (1921-2000)}

Russell Mathews was born on 5 January 1921 in Geelong and attended Haileybury College in Melbourne, where he was dux of the school. ${ }^{10} \mathrm{He}$ went straight from school to work and studied accountancy in night school in order to obtain a qualification. He saw Army service in New Guinea and Bougainville during the war, which he described in his official history of his battalion (Mathews, 1961). He rose to the rank of Captain and was cited for bravery. But he sustained a serious leg injury,

\footnotetext{
${ }^{5}$ As will be noted below, accounting courses were offered by part-time instructors in Australia as early as 1902, beginning at Adelaide (Edgeloe, 1989).

6 In the 1930s and $1940 \mathrm{~s}$, Baxter also wrote important articles and a book on accounting and business history.

7 For a list of Fitzgerald's publications, see Chambers et al. (1965: 226-240). For a profile of Fitzgerald, see Burrows (1989).

${ }^{8}$ This belief was confirmed by Ken Wright and Jean Kerr in letters to Zeff dated II August and I September 2000, respectively.

${ }^{9}$ Letter from Wright to Zeff, dated 23 April 2000 . Harcourt (1982: 1-2) acknowledges the benefit that an economist derives from this relationship.

10 'Dux' means that he was the school's outstanding scholar, i.e., he topped the examination averages or won the most subject prizes.
} 
and he limped for the rest of his life (Karmel and Barton, 2000). After the war, he enrolled in the University of Melbourne under the Commonwealth Reconstruction Training Scheme, which enabled ex-servicemen and women to study full-time. In 1950 , he graduated with a four-year honours Bachelor of Commerce (B.Com.) degree, majoring in economics but with a substantial accounting content." He qualified as a member of the Commonwealth Institute of Accountants. ${ }^{12}$

Following graduation, he moved to Canberra to become a personal assistant to Sir Douglas Copland, the first Vice Chancellor of the recently established Australian National University. 'Russell's major task,' writes Allan Barton, 'was to recruit some of Australia's most prominent academics to return to Australia for the new research university' (Barton, 2000a).

In 1953, Adelaide's economics professor, Peter H. Karmel, who had taught Mathews at Melbourne, brought him to Adelaide as reader in commercial studies, and Mathews was given responsibility for the courses in public administration and public finance, as well as in accounting and commercial law. He thus became Adelaide's first full-time teacher of accounting, even though accounting instruction at the university had begun in 1902 (Goldberg, 1981: 6; Edgeloe, 1989; Mathews, 1964b). The distinctive features that he introduced into his first-year accounting syllabus were replacement cost accounting and consolidations. Wright recollects: 'His reasoning was that the compulsory first-year subject, which he named "Elements of Accounting", should introduce future economists to those two techniques. Consolidations were considered important for economists because consolidation accounting is the basis of the National Accounts' ${ }^{33}$ The textbook that Mathews wrote in 1962 carried the title, Accounting for Economists (to be discussed below).

Mathews' preferred emphasis on the education of economists was made easier by the fact that the 'the South Australian Institute of Technology, with its own School of Accountancy, was situated immediately adjacent to the University. It would have been wasteful for the two institutions to run very similar courses. Since the SAIT was committed to providing courses leading to professional accountancy qualifications, it was decided that the University's programme should emphasise the needs of students who did not necessarily intend to take up accounting as a profession' ('The University of Adelaide', 1973: 424). The second unit in the accounting stream of the Bachelor of Economics (B.Ec.) course treated the managerial uses of accounting, and the third year was intended mainly for future accountants, but the work in accounting theory was 'solidly grounded in economic theory' (p. 424). ${ }^{14}$
In 1953, Mathews described the objectives and structure of the new courses in accounting as follows:

'In designing the new courses in accountancy we have been influenced by two broad considerations: first, the need to go back to first principles and to provide where possible a theoretical basis for the practical work in accounting methods that must necessarily occupy so much of our time; and second, the need to relate our courses in accounting to the work done in the social sciences of economics, law, statistics, political science, etc. The emphasis throughout will be on theory and principles rather than on techniques, and the approach will be logical rather than mechanical.' (Mathews, 1964c: 3)

In 1962, the year in which he published Accounting for Economists, Mathews elaborated on his strong views regarding university education in accounting:

'...I believe university work in accounting should be analytical rather than merely descriptive. If a subject is to establish itself as a university discipline it must be intellectually challenging, that is to say it must operate as a mental discipline, and it must have a place on the advancing frontier of knowledge. I believe that accounting can meet these tests, but only if it is developed as an analytical tool with emphasis on theory rather than on descriptions of current practice, with emphasis on why rather than how.' (Mathews, 1964a: 24)

He said he started from the position that 'accounting, although one of the basic social sciences, is the hand-maiden of economics' (p. 26).

Mathews was, from the very beginning of his academic career, deeply interested in macro-accounting issues, and one of his early themes was social accounting. His first published article, written while he was an undergraduate student, was 'Government Accounts for Social Accounting' (1948). In 195I, his 12th Commonwealth Institute of Accountants' research lecture was titled 'New Horizons in Accounting: The Application of Accounting Techniques to Problems of Social

\footnotetext{
"Geoff Burrows has written that Russell's 'overall record. with only one $\mathbf{P}$ and the rest $\mathbf{H} 1 \mathrm{~s}$, has rarely been surpassed'. E-mail message to Zeff, dated 26 July 2000 . Allan Barton, who was an honours graduate the University of Melboume in 1954 , agrees. Letter from Barton to Zeff, dated 10 August 2000 .

12 In 1953, the Institute combined with another body to form the Australian Society of Accountants, which is known today as CPA Australia.

${ }^{13}$ Letter from Wright to Zeff, dated 12 May 2000.

${ }^{14}$ A description of the course content of the B.Ec. degree is given in an article, probably written by Ken Wright, in The Australian Accountant ('The University of Adelaide', 1973).
} 
Accounting' (1952). Five years later, he gave the Australian Society of Accountants' research lecture at the University of Melbourne on 'Government Accounts and Social Accounting' (1957).

In 1958, Mathews was promoted to become Adelaide's first professor of commerce. He was instrumental in establishing a Master of Business Management degree, which was to comprise two years of full-time study followed by a thesis. After overcoming initial opposition from the University's education committee, in 1960 Mathews succeeded in gaining approval for the degree, which was the first of its kind in Australia (Mathews, 1964c: 10). ${ }^{15}$ It was launched in 1962, and Allan D. Barton, who had joined the Adelaide staff in 1959 as a lecturer in economics and had received a $\mathrm{PhD}$ in economics from the University of Cambridge in $1961,{ }^{16}$ was appointed to the new position of senior lecturer of business management. Ken Wright, who came to Adelaide in 1962 as senior lecturer in commerce and also was to give instruction in the MBM programme, recalls:

'Russell had his heart set on a full-fledged graduate school of business at Adelaide. But enrolments in the initial years continued to be very small, and the [University's] Development Committee apparently took the view that the number of students did not justify additional appointments. Russell was quite disenchanted'. ${ }^{17}$

Also in 1958, Mathews played an active role in the founding of what was to become, two years later, the Australian Association of University Teachers of Accounting (AAUTA) ${ }^{18}$ (Goldberg, 1987: 13-40). He served as the body's president in 1963.

Mathews, together with economist Peter Karmel, stimulated the interest of a number of young academics in the commerce and economics departments, most of whom went on to occupy chairs and have distinguished academic careers. Those who made significant contributions to accounting included John McB. Grant, Geoff Harcourt, Wright, Barton, James W. Bennett, Robert H. Parker, Scott Henderson and Graham Peirson. ${ }^{19}$ Mathews' first book, Inflation and Company Finance, published in 1958, was co-authored with Grant. It presented a statistical analysis of the accounting effects of inflation on Australian company profits and finances during the years of postwar inflation. The book was said to be 'the first study in Australia of the impact of inflation on corporate profits and finance' (Karmel and Barton, 2000). Much of the book drew on journal articles that Mathews and Grant had recently published. Grant writes that Mathews was 'the initiator and primarily responsible for Chapter $2^{\prime} \cdot{ }^{20}$ Grant was responsible for most of the statistical analysis (see Section $\mathbf{4 . 1}$ for further discussion of this work).

Both in Inflation and Company Finance and Accounting for Economists, Mathews advocated the use of valuation adjustments for stocks and fixed capital assets. He did not favour the application of a general price-level index to historical cost data (see Mathews, 1965a). Parker has written that, in Mathews' Accounting for Economists, 'it was typical of RM not just to get the theory right but also to produce a workable solution (two relatively simple adjustments in the P\&L account) rather than insisting on total reform of HCA [historical cost accounting]'. Parker added that Mathews' book with Grant 'also greatly influenced me'.21 It also influenced many others, including economists, such as Geoff Harcourt, who writes that his Cambridge PhD dissertation "was in effect Mathews and Grant for the UK (with a bit of Joan Robinson's The Accumulation of Capital [1956] thrown in)'. ${ }^{22}$

Mathews contributed to the writing of the chapter that dealt with accountancy education in the Commonwealth's Martin Report on the future of tertiary education, issued in 1964, and in the following year he criticised the Vatter Report (1964), sponsored by the professional accountancy bodies, because it proposed a continuing intrusion by the bodies into the educational policies and practices of the universities. Mathews favoured a liberalised undergraduate program, in which students would study, in conjunction with accounting, such related disciplines as economics, statistics, mathematics, law and the behavioural fields, with a requirement

\footnotetext{
15 New South Wales inaugurated Australia's first M.B.A course in 1962 .

16 Barton, who had graduated from the University of
} Melbourne with a first class honours degree in commerce, with majors in accounting and economics, thus became the first Australian accounting academic to earn a doctorate. In fact, two New Zealanders, G. Bernard Battersby and Trevor R. Johnston, were the first accounting academics in the antipodes to obtain doctorates: Battersby, at the University of Canterbury, obtained a $\mathrm{PhD}$ in business finance from the University of London in 1951, and Johnston, at the University of Auckland, received a $\mathrm{PhD}$ in economics from Cambridge University in 1954

${ }^{17}$ Letter from Wright to Zeff, dated 12 May 2000.

${ }_{18}$ In 1964, Australian became Australasian, and in 1972 the name was changed to the Accounting Association of Australia and New Zealand so as to broaden the membership to include those at non-university colleges (Goldberg, 1987: 50-51, 62-63). Subsequent references to the Association will use Australasian, which embraces both Australia and New Zealand.

${ }_{19}$ Parker is English and the others are Australian. Gibson has remarked that a number of those who fell under Mathews' spell at Adelaide 'subsequently have joined in the advocacy of current cost accounting' (1984: 241).

20 Letters from Grant to Zeff, dated 23 May 2000 and 20 July 2000 .

21 E-mail message from Parker to Zeff, dated \ June 2000. 22 Note from Harcourt to Whittington, dated November 2000 . 
that they study in depth some of these latter subjects. His view was that 'the primary role of the universities is to develop accounting as an academic subject; if they have a role at all to play in the field of professional education, it is at the postgraduate and not the undergraduate level' (1965b: 3B-15). He opposed a possible consequence of the Vatter Report, namely, that accounting research should be focussed primarily on the needs of the profession and not as an academic subject in its own right (p. 3B-10).

In 1964, the Australian National University announced a new department of accounting and public finance, which 'had been established to attract Russell back to the ANU', as he 'always believed in the merits of combining the accounting and economics disciplines as much as possible' (Karmel and Barton, 2000). He applied for and received the new chair, and he moved to the ANU at the end of the year.

At the ANU, Mathews continued his interest in accounting, although, with the founding in 1972 of the Centre for Research in Federal Financial Relations, of which he became director, the larger questions of public finance came to occupy almost all of his time and interest. Between 1965 and 1972, he published his last four articles on accounting theory, ${ }^{23}$ including one on methodology, with John W. Buckley and Paul Kircher (1968), which he had proposed doing during his year as visiting professor at the University of California, Los Angeles, in 1966. ${ }^{24}$ Also, between 1965 and 1972, Mathews served on the Accounting and Auditing Research Committee of the Accountancy Research Foundation (Burrows, 1996: 196), a body just created by the organised accountancy profession that was to sponsor pure and applied research in accounting and auditing.

In comparison with Chambers, whose long professional career of more than 40 years was as an accounting academic, Mathews and, as will be seen, Gynther were accounting academics for periods of less than 20 years each.

In 1971, Mathews wrote The Accounting Framework, a textbook styled as a revised edition of Accounting for Economists. In his preface, he issued a stern pronouncement on the state of accounting when he entered academe:

'During the first half of the 20th century....accounting became increasingly remote from reality, as complex allocation procedures, implicit valuation assumptions and the possibility of arbitrary choices among alternative valuation or procedural rules combined to make accounting information irrelevant for many of the uses it purported to serve. By the end of the half-century, it is not too much of an exaggeration to say that accounting had become a great illusion enacted before a credulous business community, the members of which thought they were receiving information related to their decision-making responsibilities but who were instead often being fed irrelevant or misleading data based on stylised accounting conventions.' (p. xiii)

Strong stuff, indeed. He hastened to observe that, in the last 15 to 20 years, there had been 'a significant change in direction', with the emergence of accounting as an information system, the increasing use of quantitative analysis to test the usefulness of accounting information, and the growing importance of systematic theories of valuation in place of rules of thumb in income measurement (pp. xiii-xiv).

Barton has written: 'Along with his academic work, Russell was keenly sought after by governments of both persuasions for advice on all matters to do with taxation and fiscal federalism' (2000a). ${ }^{25}$ In 1974-1975, in the middle of a decade of mounting inflation, Mathews chaired an Australian Government committee to study the effects of inflation on taxation. Among the recommended reforms in the Mathews Report (Report of Committee of Inquiry into Inflation and Taxation, 1975), as it came to be known, were a stock appreciation adjustment and a depreciation valuation adjustment, both on a replacement cost basis, which dovetailed with the argument that Mathews had been making for profit measurement since the 1950s. The report was said to have introduced the current cost revolution in Australia' (Tweedie and Whittington, 1984: 267), much as the report of the Sandilands Committee (1975) did in the UK. (See Section 4.1 for further discussion of the Mathews Report.)

During Mathews' service on the interim board of management of the newly created Australian Graduate School of Management, it was he who persuaded Philip Brown, then at the University of Western Australia, to become the School's foundation director in $1975 .^{26}$ In this respect, Mathews gave a boost in Australia to the market-based research in accounting and finance in which Brown was a leader.

Mathews served as a consultant to government bodies as well as a member or chairman of a number of other Government commissions and committees of enquiry, including the Review of the Accounting Discipline in Higher Education, which

\footnotetext{
${ }^{23}$ We exclude from this count a reply (1967) and a rejoinder (1968) relating to his review article in the Journal of Accounting Research (1965a). These are discussed in Section 4.I.

${ }^{24}$ Telephone interview with John W. Buckley, 16 June 2000.

${ }^{25}$ Mathews' work in these areas is surveyed in Grewal and Barton (2000), which includes a useful list of the major publications.

${ }^{26}$ E-mail message from Brown to Zeff, dated 25 August 2000 .
} 
he chaired. The review panel's report, rendered in 1990 , made sweeping recommendations with respect to funding, degree structure, teaching and research. The Mathews Report, as it also came to be known, was a factor leading to consideration of the funding of salary supplementation out of either recurrent funds or funds from full-fee paying students. Its proposal for a 'broad-based' three-year curriculum, followed by a fourth year leading to a professional accounting qualification, did not, however, come to pass. In all, the Mathews Report did not have a considerable impact at the time.

During his long service on the Commonwealth Grants Commission, from 1972 to 1990 , he was the principal author of many of its reports (Karmel and Barton, 2000).

Karmel and Barton have written:

'Russell always combined accounting, economics and finance. He was a firm believer in normative approaches to economic enquiry that would assist in policy analysis. He strongly supported the need for social justice and full employment, and in this regard, he was an advocate of Keynesian policies for macro-economic management and Galbraithian policies for public sector infrastructure.' (2000)

Russell Mathews retired and was made professor emeritus in 1986. His public service was recognised by a CBE in 1978 and an AO (Order of Australia) in 1987. During his long career, he wrote or edited 43 books, produced 47 official reports, and wrote in excess of 250 articles, encompassing accounting theory and education, fiscal federalism, taxation theory and policy, and public expenditure theory and policy (Barton, 2000a).

Allan Barton, his longtime colleague and friend, remembered Russell Mathews as 'a gentleman in every way. He was always polite, considerate, compassionate, friendly, reliable, etc. He was a great person to work with. He was never autocratic - he led by example, understanding and kindness, and was always approachable.' ${ }^{27}$ Philip Brown, who served with Mathews on the 1990 review panel on Accounting Discipline in Higher Education, has written: 'Three things always struck me about Russell during the review: his eye for detail, his quick mind, and the speed with which he could write a report!' ${ }^{28}$ Russell Mathews died on 1 March 2000.

\subsection{Reginald Sydney Gynther (1921-1999)}

Reg Gynther was born on 24 September 1921 in his parents' home in Nundah, a suburb of Brisbane. His parents were working class people, and he had to leave school after his junior year to get a job and enrol as a part-time evening student. During the war, he served in the Army and rose to the rank of Lieutenant. After the war, he worked as a company secretary and accountant, and eventually as assistant manager for several companies, first in Sydney and then in Brisbane. He qualified as a member of the Australasian. Institute of Cost Accountants, ${ }^{29}$ the Institute of Chartered Accountants in Australia, and the Australasian Institute of Secretaries.

Gynther began as a part-time lecturer in accounting at the University of Queensland in 1952, and in 1959, at age 37, he accepted the first fulltime appointment in accountancy, a senior lectureship in the department of economics. When the department of accountancy was established in 1961, he became its head. ${ }^{30}$ The following year, he received a B.Com. degree from Queensland. ${ }^{31} \mathrm{He}$ was advised, however, that he could not be promoted to professor without a doctorate, and there was no one at Queensland of appropriate rank who would be competent to supervise a thesis in accounting. He was entitled to a year's study leave, and, by diligent enquiry, he discovered that the University of Washington, in Seattle, would accept him as a doctoral candidate with only a year's study in residence, but only if he already had a master's degree. He then wrote to Russell Mathews to ask if Adelaide would allow him to enrol for its Master of Economics (M.Ec.) degree by submitting a thesis in absentia. Mathews persuaded the faculty dean to accept this arrangement, in view of the unusual circumstance in which Gynther found himself. Mathews also agreed to serve as Gynther's thesis supervisor. Gynther wrote a thesis on the choice of index in accounting for price-level changes, which was an outgrowth of an article he had published in 1962. The degree was awarded in 1964, and two years later Pergamon Press published Gynther's thesis under the title, Accounting for Price-Level Changes: Theory and Procedures. (For discussion of this book, see Section 4.2.) In the book, Gynther explained his advocacy of specific price indexes for financial reporting purposes as follows:

'...it so happens that most accountants in public practice favour the use of one general index because many of their duties relate to the protection of the interests of shareholders. On the other hand, accountants in commerce and industry

\footnotetext{
${ }^{27}$ Letter from Barton to Zeff, dated 10 August 2000. Similar sentiments were expressed by Geoff Harcourt in an interview with Whittington, August 2000.

${ }^{28}$ E-mail message from Brown to Zeff, dated 27 June 2000.

29 In 1966, the Institute became part of the Australian Society of Accountants, which is known today as CPA Australia.

${ }^{30}$ The department was renamed Commerce in 1973.

${ }^{31} \mathrm{He}$ had begun his university studies on a parn-cime basis in 1941, earning his Associate in Accountancy of the University of Queensland (AAUQ) certificate in 1943. He resumed his part-time studies in 1958 and completed his work for the bachelor's degree in 1961.
} 
usually favour the use of specific indexes. The author of this book has been affected by his environment (in industry) and he is a firm supporter of the use of specific indexes for the determination of profit, for balance-sheet valuations, and for day-to-day accounting and reporting purposes.' (1966: 45)

This perspective on accounting was shared by Russell Mathews, who approached the subject as an economist concerned with the health of the business sector.

Also in 1964, Gynther somehow found time to serve as president of the AAUTA.

With the master's degree in hand, Reg Gynther was promoted to a readership. He then obtained an Arthur Andersen \& Co. fellowship and planned to spend 1965-1966 at the University of Washington, which used one of its Ford Foundation doctoral fellowships to help support his visit. His choice of topic for a doctoral thesis was a profile of the Australian accounting profession, patterned on a study by A. B. Carson of the public accounting profession in California (1958). In fact, during 1964-1965 Gynther had designed the survey instrument, had mailed the questionnaires and received the replies, and also had completed an extensive draft of his thesis, even before he arrived in Seattle; hence, the critical part of the research and writing had all but been completed before he began his year of doctoral study. Once in Seattle, he was shocked to discover the amount of coursework outside accounting that was required, as well as written and oral examinations in addition to a thesis. Undaunted, and with characteristic zeal and tenacity, Gynther completed all of the doctoral requirements just prior to leaving Seattle after $12 \mathrm{ex}$ ceptionally full months, which included some part-time teaching. ${ }^{32}$ The Doctor of Business Administration (DBA) degree was conferred in $1966,{ }^{33}$ and in the following year he published his thesis as a book entitled Practising Accountants in Australia: An Analytical Study (1967b). The book had a mixed reception. It was praised 'as a truly fine demonstration of the value of research by way of questionnaire when intelligently performed' in The Accounting Review (Dixon, 1968: 614). But Robert G. Walker, in Abacus, found the survey to be 'lacking in depth, and therefore disappointing' (1968: 94). In 1967, Gynther became Queensland's first professor of accounting.

Gynther installed a very successful honours programme in the department of accountancy, dating from the early 1960s. It was said to be 'the first in Australia to concentrate completely on honours level studies in accounting related subjects' (Yule, 2000: 21). Quite a number of his honours students entered academe and eventually were appointed to chairs..$^{34}$ While no one could be said to have been a Gynther disciple, "most who did honours under him are full of respect for all his pushing, cajoling, arguing, etc. during the honours program'. ${ }^{35}$ Gynther insisted that each of the honours students adopt some position, e.g., current cost accounting, and defend it before the class. Richard D. Morris recalls: 'we were encouraged to argue about each issue in class. He had a great gift for instilling enthusiasm about accounting theory into his students, and I can still recall us debating among ourselves after class. There was a special camaraderie among honours students, at least in my year.' ${ }^{36}$ One of his honours students, Geoff Meredith, completed a PhD under Gynther in 1969 and thus became the first Australian accounting academic to receive a doctorate from an Australian university.

Gynther recruited a strong staff, including Robert R. Officer and Ray Ball, both coming from the University of Chicago. Officer was appointed to the fledgling department of management, while Ball went to the department of accountancy. Yet Officer has written that he was 'always intellectually, socially and emotionally tied to the Department of Accounting. ${ }^{37}$ Gynther recognised the significance of the new wave of empirical accounting and finance research emanating from Chicago, and he had the foresight and courage to bring a young exponent of this research into his department, only the second in Australia to do so. ${ }^{38}$ Ball, who joined the department as professor of accounting and finance in 1972, was, at age 27, the youngest accounting professor in Australia as well as the youngest full professor in any discipline at the University of Queensland (Prospectus

12 E-mail messages from Gerhard G. Mueller to Zeff, dated
1 May and II September 2000 , communication dated 30 June
2000 from Merle Gynther (Reg Gynther's sister), and tele-
phone interview with Kermit O. Hanson, 22 July 2000 . Arthur
N. Lorig was the chairman of Gynther's doctoral committee.
and Mueller was a member of the committee. Hanson was
dean of the University of Washington business school at the dean

${ }^{33}$ In the 1970s, the University of Washington retitled all DBA's as PhD's.

${ }_{34}$ 'Of the Honours graduates with academic careers, most have obtained further postgraduate awards. Approximately half of their number have been awarded $\mathrm{PhD}$ 's in USA and in Australia' (M. Gynther, 1990: 341).

${ }^{35}$ E-mail message from Frank Finn to Zeff, dated 8 May 2000. Finn obtained an honours degree from Queensland in 1969 and is currently head of the department of commerce. Among the others who did at least some honours work under Gynther and who then embarked on academic careers were Allen Craswell, Peter Dodd, Allan Kleidon, Richard Leftwich, Terry Marsh, Geoff Meredith, Richard Morris, Stephen Penman, Barry Spicer, David Watson, Ron Weber and Greg Whittred.

${ }^{36}$ Letter from Moris to Zeff, dated I5 May 2000.

${ }^{17}$ E-mail message to Zeff from Officer, dated 28 August 2000.

${ }^{38}$ In 1968 , Philip Brown, fresh from Chicago, went to the University of Western Australia as reader in accounting. He became UWA's foundation professor of accounting in 1970. 
2000/Department of Commerce, 2000: 19). Finn (1999) has written that 'Ray Ball's appointment totally changed the research emphasis and culture in the Department, and much of what the Department does today has its foundations in that appointment in 1972'. Ball left Queensland in 1976 to accept one of the foundation chairs at the new Australian Graduate School of Management, in Sydney.

Gynther also introduced the first dual degree in Australia linking commerce and law, which today 'is one of the most popular degrees for graduates and practitioners in both the legal and accounting professions in Australia' (Finn, 1999).

Most of Gynther's articles dealt with the theoretical and practical aspects of accounting for price changes; and he was a tireless advocate of current cost accounting. His three articles in The Accounting Review attracted considerable attention: "Accounting Concepts and Behavioral Hypotheses' (1967a), 'Some "Conceptualizing" on Goodwill' (1969) and 'Capital Maintenance, Price Changes, and Profit Determination' (1970). These are discussed in Section 4.2.

Between 196I and 1977, Gynther published 27 articles, many of which were reproduced in collections, "leaving a legacy from his 18 years few academics match in a lifetime' (Gibson, 1984: 246). In 1977, at age 55, he decided to leave academe for a policy-level position in public accounting. $\mathrm{He}$ became a national partner of Coopers \& Lybrand in Australia, with responsibilities in research and eventually also in professional education. During the inflation accounting debates in the late 1970s and early 1980s, he was the face of Coopers, speaking and writing extensively on the merits of current cost accounting. From 1977 to 1983, he was an energetic member of the Accounting Standards Committee, which was reorganised in 1978 as the Current Cost Accounting Standards Committee (CCASC). He was much involved with the preparation of the CCA Working Gujde, and he did the initial work on the committee's exposure draft on monetary items. ${ }^{39}$ (See Section 4.2 for further discussion of this work.)

Gynther also fathered the Coopers \& Lybrand Accounting and Education Research Fund, which financed research by academics and provided honours and master's scholarships. ${ }^{40}$ He retired from the firm in 1985.

In his capacity as head of the accountancy/commerce department, Reg Gynther has been described as "a totally dedicated, straight down the line leader, with a limitless capacity for hard work... [and regarded by a colleague] as "the time and motion man" because he hated to waste a minute' (Yule, 2000: 27). Gynther was keenly competitive in any endeavour he undertook, whether work or sport. ${ }^{41}$ Yule added that Gynther

"had a highly centralist style, seeing consultation as a waste of time and consensus as automatic as everyone would agree with him. Having a total commitment to the department and the advance. ment of academic accounting, Reg Gynther was prepared to take on anyone who threatened the department or queried the position of accounting as an academic discipline. Although he had very conservative attitudes, he was tolerant of personal eccentricities, provided that people pulled their weight in teaching and research.' (p. 27)

Kevin Stevenson, a former director of the Australian Accounting Research Foundation and a former technical partner in Coopers \& Lybrand, has written that, during Gynther's long service on the CCASC, "he was a mentor to many, including me, much in the mode [that he was in his department at the University of Queensland]. Reg had the ability to move between academe and practice, and the drive to do whatever needed to be done. His approach to his $\mathrm{PhD}$ was not a one-off effort it was the way he worked....His energy, understanding and capacity for work were exhausting for me'.42

Following Gynther's departure from the University of Queensland in 1977, its Senate conferred on him the title of professor emeritus. He died on 27 November 1999.

\subsection{Raymond John Chambers (19/7-1999)}

Ray Chambers was born on 16 November 1917 in Newcastle, New South Wales, the son of a Yorkshire coal miner. He was educated at Newcastle Boys' High School, and a university scholarship enabled him to enrol as a part-time student in economics at the University of Sydney. He graduated with a B.Ec. degree in 1939 (Wolnizer, 2000: 1). In 1934, he had begun studying accounting by correspondence in order to obtain a qualification (Chambers, 1991: 101-102; Chambers, 2000: 318-320).

Following three years as a stock clerk in Shell and two years as a materials control supervisor and statistical officer in a large light engineering firm, Chambers spent the further war years of 1943-1945 on the regulatory staff of the Australian Prices Commission (Chambers and Dean, 1990: 287; Chambers, 1991: 102). There, as Chambers has written:

'I was engaged in the analysis of the financial statements and cost calculations of firms. Prices

\footnotetext{
${ }^{39}$ E-mail message from Kevin Stevenson to Zeff, dated 24 July 2000

40 E-mail message from Stevenson to Zeff, dated 19 April 2000.

41 Zeff recalls that, in a visit to Gynther's home in 1972, he defeated Gynther in several games of table tennis, which the latter never forgot.

${ }^{42}$ E-mail from Stevenson to Zeff, dated 23 July 2000.
} 
were controlled by reference both to costs and profits. Ideally the figures supplied by firms should have been derived by the same rules, so that comparisons of firms and industries could be readily made. I had previously worked in two large manufacturing companies and had some idea of the rather crude ways in which cost calculations and asset values were made. Now, confronted by the accounts of many firms in many industries, all using their own combinations of accounting rules, the impression of disorder was intensified.' (1974a: vi)

In a later retrospection, he added: 'Brought up on basic economics - the ideas of economising at least, profit maximising at best, and the adaptive behaviour which the theory of market economics entailed - there seemed to be no place for the conventional accounting stuff' (1991: 103).

By 1943, he had qualified as a member of the Commonwealth Institute of Accountants, ${ }^{43}$ the Australasian Institute of Cost Accountants, and the Australasian Institute of Secretaries.

Chambers began to lecture part-time in auditing in Sydney Technical College, and then in 1945 he became a full-time lecturer in the College's new course in financial management. He taught in all facets of the College's programme, including accounting. He continued to be vexed by 'the coexistence of different accounting rules yielding figures of greatly varying quality. How discriminating managers, investors and creditors could use such figures was at least puzzling' (1974a: vi). When he discovered the need for a textbook to link accounting with financial administration, he wrote Financial Management (1947). It was, he later wrote, 'the product of my first two years as a full time teacher' (1991: 105). Although its author had not yet reached his 30th birthday, the book was a mature and comprehensive work, which demonstrated a commendable awareness of the leading American and British and Australian literatures. Goldberg called it 'the first book of its kind in Australia' (1981: 32). ${ }^{44}$

During the early $1950 \mathrm{~s}$, Chambers gave a series of research lectures at Australian universities, and these, together with a triptych of lectures for a refresher course sponsored by the Commonwealth Institute of Accountants, were published in The Australian Accountant, which, under the enlightened editorship of Alexander Fitzgerald, became a favoured outlet for academics. The research lectures represented his first forays into theory development, in which, among other things, he proposed a future orientation for the financial statements (Chambers, 1952a). 'That experience,' he later wrote in reference to his extensive study of the accounting literature in the course of preparing the research lectures, 'revealed many specific points at which conventional doctrine and practice were financially wayward and logically fallacious.... To point out these flaws, and to attempt to eradicate them, seemed to be a game well worth the candle' (1991: 23). In his refresher lectures, he explored the relation between accounting information and its internal and external users, including contemplations on how best to reflect the effects of the postwar inflation in accounting reports.

In 1953, he moved to the University of Sydney as senior lecturer in accounting, the first full-time appointment in accounting at the university, even though the subject had been taught there since 1907 (Brown, 1982: 100). A scant two years later, he was promoted to associate professor of accounting, the first appointment at that level in accounting at any Australian university. ${ }^{45}$

It was in the mid-1950s that Chambers took the first bold step to erect his theory as well as to repair the literature. He has written as follows:

'The textbooks and much of the periodical literature of the fifties gave the impression that most writers were too fond of prescribing to spend time or energy in observing what was going on about them. The literature was dogmatic. Many of the things being done in practice were either disregarded or dismissed as improper. Some of the literature purported to be theoretical. But [it] was short on analysis, loose in argument and ambivalent in conclusion. I proceeded with two kinds of work in parallel[:] observing accounting practices and their consequences, and trying to put into some coherent order the general ideas which were held to constitute the theory of accounting.' (1974a: viii)

His first major article on theory construction, as well as his first paper published outside of Australia, was 'Blueprint for a Theory of Accounting', which appeared in the British journal Accounting Research (1955a). He later described it as

'a tentative expression of my aim and method. It stated that the foundations of a theory of accounting lie in the environment of economic realities; that there is a need for a general theory of accounting which would provide the basis for theories specific to different classes of entities; and that, on grounds of usefulness, accounting summaries should be expressed in currently relevant terms' (Chambers, 1962: 46). ${ }^{46}$

\footnotetext{
${ }^{43}$ Through a series of amalgamations, the Institute eventually became part of the Australian Society of Accountants, which is known today as CPA Australia.

${ }^{44}$ For his further reflections on this period of apprenticeship', see Chambers (1991) and (2000).

is Louis Goldberg, at Melbourne, was the next associate professor, in 1957.

46 This unpublished paper was written in 1962 and is reproduced, together with the rest of Chambers' papers, in Chambers and Dean (1986/2000).
} 
He began by quoting John B. Canning's observation that the accountants have no complete philosophical system of thought about income nor is there any evidence that they have ever felt the need for one' (1955a: 17). Chambers was critical of accounting writers who seemed content to describe practice rather than propound 'a theory of accounting' (pp. 17-18). He then demonstrated how a theory might be constructed, and he proposed and defended a set of four propositions that 'lie outside of the field of accounting proper' (p. 19) together with several implied corollaries. A. C. Littleton, who viewed accounting theory as a distillation of accounting practice, responded with two articles in which he criticised Chambers' view that a theory could be framed without reference to this practice $(1956 \mathrm{a} ; 1956 \mathrm{~b})$. In particular, he objected to Chambers' suggestion that a technology of price-level adjustments should be injected into accounting, an alien ideology that Littleton had opposed during his long and distinguished career. Littleton deliberately published one of his two articles in The Australian Accountant, on Chambers' home turf.

Also in 1956, by coincidence, Chambers published a detailed and critical review of Littleton's magnum opus, Structure of Accounting Theory (1953), in The Accounting Review, the journal that Littleton had edited in the 1940s. It was Chambers' first article published in the US. Although he praised Littleton in the initial paragraphs, he could find little to praise in the monograph itself. Finally, he wrote, perhaps in exasperation, 'The general purport of Structure of Accounting Theory is to demonstrate the propriety of conventional business accounting method' (p. 590). Chambers' and Littleton's domains of enquiry were fundamentally different, and criticism across the methodological divide can hurt to the quick.

In 'Detail for a Blueprint' (1957a), Chambers replied to Littleton (1956b) on the latter's home turf, The Accounting Review. Showing supreme confidence, he dismissed Littleton's points one by one, and he claimed that Littleton's defence of historical cost accounting "is an excellent example of what is a very common logical fallacy: post hoc ergo propter hoc' (p.211). He remarked that 'Professor Littleton's approach to accounting is essentially pragmatic,' one, he said, that 'leads to oversimplification' (p.214). Aged 39 and not yet a full professor, Chambers had bearded one of the lions of US academic accounting, a professor emeritus who had just been inducted into the Accounting Hall of Fame. Littleton never came to terms with Chambers' criticism, which he took as an affront. ${ }^{47}$

The second half of the $1950 \mathrm{~s}$ and the early $1960 \mathrm{~s}$ were an especially busy time for Chambers. He published two books, The Function and Design of Company Annual Reports (1955b) ${ }^{48}$ and Accounting and Action (1957b), gave three research lectures, wrote some two dozen articles, and at Sydney introduced an honours programme in accounting. In 1958-1960, he played a leading role in the founding and establishment of the AAUTA, and he served as its first president in 1960-1961 (Goldberg, 1987: 13-48). In 1960, he became Sydney's first professor of accounting, and he began 15 years as head of the new department of accounting. His teaching staff in accounting was still small: one senior lecturer and three part-time lecturers (Brown, 1982: 101). In 1962, in order to foster a dialogue between academic and practising accountants, Chambers founded the Sydney University Pacioli Society (Wolnizer, 2000: 2).

In 1959 and 1962, Chambers took extensive trips overseas, visiting many universities, spending two months as a consultant on the research staff of the US Accounting Principles Board (APB), ${ }^{49}$ and attending the Eighth International Congress of Accountants and the annual meeting of the American Accounting Association. ${ }^{50}$ Accounting Research had ceased publication in 1958, and during his tour in 1962 he began to look into establishing a journal to fill the void. At one time, he considered co-sponsoring, together with the London School of Economics, the new Journal of Accounting Research, which the University of Chicago launched in 1963 (Davidson, 1984: 283-284), but instead, with the support of Goldberg, Mathews and Roy Sidebotham (of Victoria University of Wellington, New Zealand), who composed the editorial board, he opted to found his own journal, Abacus, in 1965 (Brown, 1982: 101; Wells, 2000). It was a characteristically bold scheme, as the output of academic accounting research in Australia and New Zealand probably could not have justified an antipodean journal. To provide a broader net, Abacus was styled as 'A Journal of Accounting and Business Studies', and four of the 10 main articles in the first two issues fell in the latter category. ${ }^{51}$ Chambers served as editor of the journal until 1974, and he continued as an active "editorial con-

\footnotetext{
47 Interview by Zeff with Littleton, July 1964.

${ }^{48}$ A reviewer in Accounting Research wrote, 'This interesting book by Professor Chambers is the only one known to the reviewer that attempts exhaustively to examine the case for giving copious individual accounting information to a wider audience than receives it under the present practice' (Nightingirl, 1956: 399).

4 For a recollection of Chambers' visit to the APB's research staff, see Moonitz (1982).

${ }^{50}$ For a report on his 1962 trip, see Chambers (1963a).

sI For a discussion of the difficult, early years of editing Abacus, as well as the events that led up to its founding. see Chambers (1969a) and Wells (2000).
} 
sultant' until his death (Dean, 2000: ii).

During the early $1960 \mathrm{~s}$, Chambers published three important papers dealing with the content and method of his emerging theory. Pride of place belongs to the monograph based on his research lecture at the University of Adelaide, Towards a General Theory of Accounting (1961). Russell Mathews, who invited Chambers to deliver the lecture, regarded this monograph 'as the watershed between the old style of pragmatic accounting and the new theoretically based accounting in which Chambers was to play such a dominant role in developing it during ensuing years' (1982: 177). He added that 'it was not until 1961. that I came to full realisation that Chambers was an intellectual giant, who was in the process of transforming accounting from a technical set of arbitrary rules into a rigorous conceptual framework and measurement system' (p. 177). This 48-page monograph anticipated his Accounting, Evaluation and Economic Behavior (AEEB) (1966b) both in content and method: it was a densely written, tightly logical exposition (a 'layer cake', as he called it) of 40 foundational statements, or postulates, about the characteristics of the world of action, together with 21 derived statements, or principles, related to accounting. ${ }^{52}$ Mathews recalled, without exaggeration, that 'The lecture itself left the audience somewhat bemused, because the structure of ideas and the complexity of the theoretical framework developed by Chambers could not be easily grasped from an oral presentation' (p.177). The publications committee of the Australian Society of Accountants, which sponsored the lecture, 'decided that it was not prepared to publish the lecture in any form', and it was finally published only at the insistence of the University of Adelaide, and was partially subsidised by Chambers (p.177). One important difference between the 1961 monograph and $A E E B$ was the former's adoption of replacement cost as the valuation system for non-monetary assets. Chambers' important transition from replacement prices to resale prices is discussed further in Section 4.3.

The year before his research lecture was deliv. ered, Chambers published 'The Conditions of Research in Accounting' (1960), which outlined the scientific method he would use in the lecture. $\mathrm{He}$ wrote another methodological piece, 'Why Bother with Postulates?', in the inaugural issue of the Journal of Accounting Research, in which he argued, somewhat in reaction to Moonitz (1961), that it is necessary 'to consider a whole system of postulates and a conclusion together'. 'There is', he said, "no such thing as a set of postulates which is independent of a set of conclusions or principles or hypotheses' (1963b: I3).

In the 1960s, Chambers critically analysed the ideas of leading writers in several papers: 'The
Resolution of Some Paradoxes in Accounting' (1963c), 'Conventions, Doctrines and Common Sense' (1964b) and 'The Development of Accounting Theory' (1965b). In the 1960s and 1970 s, he wrote penetrating review articles on the treatises by Edwards and Bell (1965a), ${ }^{53}$ Mattessich (1966a), Fisher (197/a), ljiri (1972b) and Canning (1979), as well as on the American Institute of Certified Public Accountants' accounting research studies 1 and 3 on postulates and principles (1964a), 6 on price-level accounting (1966d), and 7 on generally accepted accounting principles $(1966 \mathrm{c})$. All of these articles repay a careful reading by anyone seeking a deeper understanding of the works, as they well typify Chambers' laser beam of analysis. While he liked to say that he had no more than a 'spotty' understanding of others' writings, ${ }^{54}$ he was indeed a thorough and incisive analyst of every work that he addressed.

In February 1966, Prentice-Hall published Chambers' monumental work, Accounting. Evaluation and Economic Behavior (AEEB, 1966b). It embodied his complete theory of accounting, which he called Continuously Contemporary Accounting. As an ideal, Chambers rejected replacement cost in favour of 'current cash equivalents', or selling prices - also known as exit values, a term coined by Edwards and Bell (1961: 79). Yet he 'resorted to replacement prices as a means of getting an approximation to current cash equivalents on an ideal basis, both when dealing with short-term inventories and when suggesting methods of obtaining evidence of current resale prices of durables...' (1966b: 249). His overriding concern was to provide accounting information that was relevant to the firm's capacity for adaptation to changes in its environment, and he concluded that, in principle, only 'current cash equivalents' would suffice.

Chambers had signed the contract with PrenticeHall in 1962, when visiting the US, and the writing of the manuscript occupied all of 1963 and 1964 (Chambers, 1974a: xiv). Like his 1961 research lecture, but on a much larger scale, the book was densely written and, from the most primitive propositions to the conclusions and implications for accounting, was rigorously logical. At the end

\footnotetext{
52 Chambers has said that his curiosity about how people act, i.e., solve problems, was 'sparked off' in part by a high school mathematics teacher who brought into his class a number of logical word problems, which, he said, were exercises in mathematical analysis. (Interview by Zeff with Chambers, 14 January 1967.) In the same interview, he cited von Mises (1949) and Robbins (1932) as being particularly influential in the development of his ideas in the 1961 research lecture.

${ }^{53}$ In 1982, Chambers continued his analysis and criticism of Edwards and Bell (1961) and included later writings by both Edwards and Bell.

$\$ 4$ Interview by Zeff with Chambers, 14 January 1967
} 
of the chapters, he summarised the argument by concisely stating more than four hundred postulates and definitions as well as inferences and conclusions. He dutifully traced his methodological and theoretical debt to philosophers, linguists, psychologists, decision theorists and scientists (among others), and, on matters close to accounting he drew on the economics, finance and accounting literatures. It was a weighty and intricately woven tome. (For a further discussion of $A E E B$, see Section 4.3.)

The reviews were admiring but critical (McDonald, 1966; Wright, 1966; Dein, 1966; Solomons, 1966; Cruse, 1967; Benston, 1967; Hendriksen, 1967; Baxter, 1967). In his review, Wright said that 'the author has struck an important blow for the adoption of contemporary prices as the basis of accounting: the care with which he has developed the logical structure of his argument will make it impossible to dismiss his conclusions, and difficult to demolish them' (1966). Yet Chambers had opened himself to criticism for accepting replacement prices when resale prices were not readily available for short-term inventories. In 'Second Thoughts', his first general reply to his critics, Chambers responded by coming down unequivocally in favour of resale prices for all classes of inventory (1970). This, and related issues, are discussed in Section 4.3.

In 1967, AEEB was honoured as a Notable Contribution to the Accounting Literature, a recognition jointly conferred by the American Accounting Association and the American Institute of Certified Public Accountants. Two years later, Arthur Andersen \& Co. paid him the unique tribute of reprinting more than 50 of his papers in a volume entitled Accounting, Finance and Management (1969b). In 1973, the University of Sydney conferred upon Chambers a Doctor of Science in Economics (D.Sc.Econ.) degree based on $A E E B$ and his other published writings.

From the late 1960 s onward, Chambers battled against 'value to the business' (1971b), multiple column reporting $(1972 \mathrm{a} ; 1972 \mathrm{c})$, both general purchasing power accounting and current cost accounting (e.g., 1967a, 1975a, 1976c, 1978a), ${ }^{53}$ the argument that it is impossible to set an accounting standard that would be preferred by all individual users (1976b), and both market-based research and positive accounting theory (1993). Numerous writers crossed swords with Chambers in the literature, but few would take him on in seminars or conferences. He was a formidable debater, and any concessions he might make, and they were few, were well disguised in return thrusts of his own. Some found his manner at times to be disdainful, although he loved a good argument. Mathews wrote that, "An adversary could be irritated by the sense of superiority or even condescension which
Chambers sometimes displayed in his writings, but his arguments could never be ignored' (1982: 176-177). We shall see later, in our discussion of the debate between Chambers and Gynther, how provocative Chambers' style of debate could be.

In 1976, Chambers was the first person chosen by the American Accounting Association to tour North American universities as Distinguished International Visiting Lecturer, In 1977-1978, he served as national president of the Australian Society of Accountants. And in 1978 he was honoured with an $\mathrm{AO}$.

Chambers devoted much of the remainder of his career to replying to critics, clarifying his views, and, with unflagging energy and missionary zeal, advocating the acceptance of his views by all concerned (e.g., see Chambers, 1970, 1974b, 1975b, 1976d, 1978a), publishing articles and lecturing throughout the world. ${ }^{56}$ In a book, Securities and Obscurities, he used an earthy approach to enlarge the audience for his reformist theory. Rather than restate his elaborate theoretical argument, he instead examined scores of opinions of analysts, journalists, economists, accountants, executives, jurists and other classes of commentator to demonstrate that the existing [accounting] practices, even of companies that are well esteemed, are inadequate, uninformative, and often obscurantist.... [and to establish] a case for the reform of present laws and practices' (1973: ix).

Chambers' major accomplishment, in terms of practical effect, was to secure a serious consideration of exit value by accounting academics (especially in their teaching and in their textbooks on accounting theory) and by accounting policy makers and governmental committees of enquiry in the US, UK, Canada, Australia and New Zealand (for particulars, see Zeff, 2000: 8-9). Moreover, in the mid-1970s, five New Zealand companies, including the country's second largest corporation, adopted 'continuously contemporary accounting' in a supplementary exhibit to their annual financial statements, and Chambers was brought in as a consultant (Trow and Zeff, 1976: 342; Chambers, 1976a).

He retired from the university in 1982 and was made professor emeritus. But that act of retirement, required by university statute, did not slow

\footnotetext{
${ }^{55}$ After hearing Chambers' demonstration, by 'resolute inquiry', that his 'continuously contemporary accounting is logically and practically imperative' and that $i t$, and only it, meets the criteria of a superior accounting system $(1967: 26,42)$, the American theorist Carl L. Nelson remarked that Chambers' presentation "is the proclamation of an impatient individual a person who is far nore impatient than would be expected of the author of Accounting, Evaluation and Economic Behavior' (1967: 50).

So Abactis, however, was by far the predominant place in which his work was published, with 30 articles appearing there between its first volume in 1965 and 2000.
} 
his pace of production. Chambers continued to speak and publish extensively into the 1990s. In 1995, he published a mammoth thesaurus covering 500 years of accounting, a work that only he could have produced. His encyclopaedic knowledge of the accounting literature, as well as his deep and abiding interest in the evolution of ideas, are richly on display in this beautifully crafted work. It was a fitting valediction to a career devoted tirelessly to the improvement of the accounting discipline.

In 199I, Chambers received two accolades. He was chosen by the American Accounting Association to receive an Outstanding Accounting Educator Award, and he was inducted into the Accounting Hall of Fame. He was the first recipient of the AAA award not from a US university and was only the second member of the Hall of Fame from outside of North America. In 1996, the Accounting Association of Australia and New Zealand (successor to the AAUTA) gave Chambers one of its two inaugural awards for Outstanding Contribution to the Accounting Research Literature ('AAANZ Outstanding Contribution...', 1996).

The final tally of Ray Chambers' published writings was 'a dozen books and well over 200 articles, monographs and reports on accounting, financial management and the law...' (Wolnizer, 2000: 1). Few have had the impact on students, on colleagues and on the field as Chambers. ${ }^{57} \mathrm{He}$ was a stimulating figure, always questioning, always probing. A Festschrift was published in the December 1982 issue of Abacus, the journal he founded, and a second appeared in its October 2000 issue. Ray Chambers died on 13 September 1999.

\section{Contributions to the debate on price change accounting}

The names of Chambers, Gynther and Mathews are inextricably linked with the debate on price change accounting that raged (not too strong a word) in the 1960s and 1970s. This extended far beyond Australia, but Australia made a disproportionately large contribution to the international debate, and these three authors were at the heart of the Australian contribution. It therefore seems to be appropriate to recount and assess their individual contributions to this debate, and some controversies that took place between them. It should also be recognised, however, that, as indicated earlier in this paper, their contributions extended far beyond price change accounting. Russell Mathews was primarily concerned with public finance issues and spent a substantial part of his career in posts that focussed on such issues. Reg Gynther entered the academic profession relatively late in his career and left it while still in his prime to take up a research post with a leading firm of chartered accountants. Ray Chambers had a long career as an academic accountant, stretching beyond his formal retirement, but he contributed to all aspects of accounting and certainly did not confine himself to price change accounting.

Before embarking on a discussion of price change accounting, it is perhaps worth recalling the importance of this subject both in practice and in academic debates of the 1960s and 1970s. A comprehensive history of the subject is provided in Tweedie and Whittington (1984).

The practical impetus for the debate was the persistent inflation that developed in most free-market economies as a result of the Keynesian economic policies adopted after the Second World War. We have already seen that this gave rise to the policy problems that Mathews and Grant (1958) sought to address. There were similar studies in other countries, such as the US and the UK, which faced similar problems at the time. The rate of inflation accelerated in the $1960 \mathrm{~s}$, when professional bodies, particularly in the English-speaking countries, started to take an interest in recommending the adjustment of accounts by general price indices. Inflation in these countries continued to accelerate, reaching a climax in the mid1970 s, by which time governments had started to take an interest in the price-adjustment of accounts for taxation and other purposes (e.g., the appointment of the Sandilands Committee in the UK, the Mathews Committee in Australia and the Richardson Committee in New Zealand). These Government-appointed bodies advocated the adjustment of accounts by specific price indices rather than general indices. A fierce international debate followed, with the result that accounting standards incorporating specific price adjustments were issued in the US in 1979 and in the UK in 1980 , and similar proposals were planned in other countries. However, both the US and the UK standards were unpopular with preparers of accounts and, at the time they were issued, inflation rates were falling rapidly under the influence of the new 'monetarist' macro-economic policies, based on restricting government expenditure and strict control of the money supply.

As a result of this, the impetus for comprehensive price change adjustment of accounts was lost: the UK and the US standards were withdrawn and other countries did not issue their planned standards on the subject. An exception was Latin America, where hyper-inflation justified requirements for general index adjustment of accounts in

57 Among Chambers' leading intellectual disciples are Frank Clarke, Graeme Dean, Atiq lslam, John Staunton, Murray Wells and Peter Wolnizer. Many others were much influenced by Chambers, jncluding Michael Gaffikin, Sidney Gray, David Johnstone, Hector Perera and Rober Walker. 
certain countries into the 1990s (Tweedie and Whittington, 1997).

The academic debate on price change accounting can be traced back to the beginning of the twentieth century (Tweedie and Whittington, 1984: ch. 2) so that Chambers, Gynther and Mathews were able to draw on a substantial existing literature. The debate was international, and they were also able to interact with scholars in many other countries. The debate was concerned with the choice of index to be used for price adjustment: should it be an index of general purchas. ing power or a specific price index, representing the price of a particular asset?

There were two distinct strands to this debate, the valuation of specific assets (and, where the value was not fixed in nominal terms, liabilities) and the measurement of capital for the purpose of calculating income. Our trio were agreed that valuation should be based on specific prices (or specific price indices) rather than using a general purchasing power index to adjust historical cost. They disagreed on the issue of which specific price should be used: Mathews and Gynther preferred replacement costs (entry values) whereas Chambers preferred selling prices (exit values). With regard to the measurement of capital for determining profit, Mathews and Gynther believed that this should be based upon maintaining the productive capability of the business entity (which implied a replacement cost adjustment), whereas Chambers believed that it should be based upon preserving the real purchasing power of the net assets attributed to proprietors (which implied a general purchasing power index adjustment).

The solution to the price-change problem that, briefly, appeared likely (in the late 1970s) to become adopted in practice was Current Cost Accounting (CCA). This was based on valuing assets at value to the business rather than replacement cost. Value to the business is replacement cost except when replacement cost is not recoverable either by use (the net present value of cash flows obtainable from continued use in the business) or by sale (the net realisable value obtained by orderly disposal). Thus, value to the business will be replacement cost in most realistic situations (Gee and Peasnell, 1976) and can be viewed as replacement cost, moderated by an impairment test. It can therefore be seen that the CCA valuation method was close to that preferred by Mathews and Gynther and distinctly different to that preferred by Chambers. The same can be said of the CCA capital maintenance concept. CCA operating profit, as advocated in UK's Sandilands Report (1975), corresponded with Mathews' preferred concept of capital maintenance. Later variants of CCA, such as the New Zealand Richardson Report (1976) and the UK's Statement of Standard
Accounting Practice (SSAP) 16 (1980) incorporated monetary working capital and gearing adjustments which captured the effects of changing prices on monetary assets and borrowing, but in terms of specific prices (those of the specific assets used and traded in by the entity). These were accepted by Mathews (although they did not feature in his earlier contributions), and welcomed by Gynther (who had adopted monetary working capital adjustments from his early study of the Philips system), but were anathema to Chambers.

In considering the contributions of the trio to price change accounting, we shall first consider their individual contributions. Russell Mathews will be discussed first, because he was chronologically the first to make a major contribution to the area. Then we shall consider Reg Gynther, because his work grew out of a thesis supervised by Mathews of whom he might be described a follower (but not a disciple). Finally, we shall consider Ray Chambers, who adopted a different approach to the other two (preferring exit values to entry values) and clashed with both of them. Having considered each individually, we shall go on to consider the clashes between Ray Chambers and Russell Mathews in 1965-1968, and between Ray Chambers and Reg Gynther in 1971-1972. We shall conclude with some observations on the impact of their respective contributions on accounting thought and practice at the beginning of the 21 st century.

\subsection{Russell Mathews and Replacement Cost Accounting \\ Although Russell Mathews devoted most of his} considerable energies to public finance issues, price change accounting was an important theme in his academic writing, not least because of its relevance to public finance, through its implications for the basis of corporate taxation.

The particular form of price change accounting preferred by Russell Mathews is best described as replacement cost accounting, rather than current cost, because he was reluctant to embrace the eclectic 'value to the business' principle supported by most advocates of current cost (e.g. the Sandilands Report, 1975). His basic approach was that price changes rendered historical cost irrelevant to current decisions, and that appropriate corrections to historical cost profit could be achieved by two simple adjustments, based on current replacement costs, a cost of sales adjustment (whose effect was to charge stocks used at current replacement cost rather than historical cost) and a depreciation adjustment (reflecting the difference between the current replacement cost of fixed assets consumed and their historical cost). He rejected general index adjustments of monetary assets and claims or of proprietors' capital, on the ground 
that they were irrelevant to the needs of a continuing business entity.

These views crystallised early in Mathews' academic career, notably in his book written with the economist John McB. Grant, who was his colleague in Adelaide (Mathews and Grant, 1958). This book represented work done from 1954 onwards and was Mathews' most substantial contribution specifically to price change accounting. It reported an empirical study of the Australian company sector in the period following the Second World War. The cost of sales adjustment and stock adjustment were estimated, using specific indices and assumptions about asset ages, and the consequent effects on the measurement of retained profits were calculated. The purpose was to consider dividend policies, tax policies and pricing policies in the light of the revised information. The conclusion of the study was that the incorporation of these adjustments in company accounts to yield what the authors described as 'current income' would provide a safeguard against over-distribution of dividends and a more equitable tax base: 'current income is a measure of the income that is available for distribution, so that both taxes and dividends should be related to it' (Mathews and Grant, 1958: 3). The study also concluded that replacement cost pricing would lead to a more efficient allocation of resources in the economy.

Of equal importance for present purposes is the theoretical basis of the study. The authors approached the problem as economists, asking questions that are important for the economy as a whole, as well as for individual companies. Mathews himself had done his honours thesis at the University of Melbourne on a topic in national income accounting, ${ }^{58}$ and his first publications were in this field. It is therefore perhaps natural that, in adjusting business accounts for price changes, he should resort to precisely the same adjustments as are used in national income accounting, the elimination of stock appreciation and the re-statement of depreciation at replacement cost. These adjustments are designed to measure income after the maintenance of the productive capacity of the entity, whether at the level of the nation or of the individual firm.

Mathews and Grant rejected the use of general indices for adjusting the values of physical assets (Mathews and Grant, 1958: 20-21), and more importantly they rejected the use of general indices for adjusting owners' capital and monetary assets and liabilities (pp. 21-23). The latter followed naturally from their view that capital maintenance should be concerned with the physical assets of the entity:

'...there are strong practical grounds for accepting accounting procedures designed to maintain the real value of capital invested in physical as- sets, but it is difficult to justify accounting procedures designed to preserve the purchasing power of cash resources and money claims'. (Mathews and Grant, 1958: 22)

The only role acknowledged for general price level adjustment was for comparison of incomes between years (not their calculation within years), 'but this is a task for the statistician rather than the accountant' (p. 23). Again, this is consistent with the approach of national income accounting, in which general price level adjustments are used to construct series of 'real GNP' to produce appropriate measures for inter-year comparison.

It was this strong stance in favour of replacement cost adjustments that led to Russell Mathews' next important contribution to the price change accounting debate. This was his critique (1965a) of an important American study (Staff of the Accounting Research Division, 1963) (ARS 6), which recommended general price-level adjustment of business accounts to reflect the impact of inflation. The title of Mathews' critique was both blunt and pertinent: 'Price-Level Changes and Useless Information'. The burden of the argument was that ARS 6 had been wrong to give priority to general price-level adjustment. Rather, adjustments for the specific price changes of the operating assets of the business should have been the main focus, to yield an operating income measure like that advocated by Mathews and Grant (1958). General price level adjustments were given a secondary role: '....adjustments designed to measure changes in the general price level only acquire meaning if they are calculated by reference to data which have themselves been valued on a consistent basis' (Mathews, 1965a: 136). Furthermore, the general price level adjustment was merely to aid inter-year comparison and was 'of relatively minor significance' (p. 137). The idea of restating owners' equity by general price level changes to maintain the real purchasing power of capital was firmly rejected, as were the related concepts of reporting a real gain on borrowing or loss on holding money in a period of inflation.

Mathews' trenchant critique of ARS 6 attracted critical response from three commentators, one of whom was Raymond Chambers. The ChambersMathews exchange will be considered in more detail later. For the present, it should be noted that this hinged primarily on Mathews' insistence on a physical capital maintenance concept and rejection of general price level adjustment for this purpose. Chambers, always a shrewd judge of his opponents' strengths and weaknesses, noted that Mathews' approach to income measurement was more suited to national income accounting than

\footnotetext{
${ }^{58}$ Interview by Whittington with Allan Barton, July 2000 .
} 
business accounting (Chambers, 1967b: 216).

The final important contribution by Russell Mathews to the price change accounting debate was associated with the Mathews Report on Inflation and Taxation (1975). This report made recommendations about the Australian system of taxation in the context of the inflation of the early 1970 s, which was more severe than that in the immediate post-war period studied by Mathews and Grant (1958). The section of the Report that dealt with business income taxation was obviously relevant to the price change accounting debate. The conclusion was consistent with the earlier views of the Chairman: for taxation purposes, companies should be allowed to deduct from their historical cost profit two adjustments, a cost of sales adjustment (equivalent to the increase in the replacement cost of stocks during the period) and a depreciation adjustment (equal to the excess of replacement cost depreciation of fixed assets over the historical cost depreciation). This recommendation was very similar to that of the Sandilands Committee (1975) in the UK which reported a few months later, although the latter was in favour of "value to the business' as the measurement method, whereas the Mathews Report favoured the narrower replacement cost method. ${ }^{59}$ The Mathews Report, unlike the Sandilands Report, was addressed specifically to taxation, rather than the wider issue of financial reporting, but Mathews made clear that he would have preferred the proposed system to be adopted for financial reporting as well as taxation. He later expressed the view that the failure of the Government to implement the Report was encouraged by the failure of business to adopt the proposals for financial reporting purposes (Mathews, 1980: 268-269)

The Mathews Report suffered a similar fate to the Sandilands Report. It led to no significant or lasting changes in the Australian system of company taxation, which dealt with inflation in the short term by a temporary stock appreciation relief, similar to that introduced in the UK. As in the UK, the pressure for reform of the tax base was lessened by the falling rates of inflation. Both reports were influential in the subsequent debate on the use of current cost accounting for financial reporting, which led, briefly, to professional recommendations for current cost accounting, although in both countries (and especially in Australia) the success of current cost was limited and short-lived (Tweedie and Whittington, 1997).

In the aftermath of the Mathews Report, Russell Mathews contributed further to the price change accounting debate. He welcomed the Richardson Report (Report of the Committee of Inquiry into Inflation Accounting, 1976), which recommended a form of current cost accounting for use in New Zealand (see Mathews, 1977). In doing this, he commended the use of the gearing adjustment, which was proposed by the Richardson Report. This adjustment was considered in the Mathews Report but did not feature in its final recommendations and had not appeared in Mathews' earlier writings. It represents a specific price adjustment method of dealing with the gain on borrowing and loss on holding monetary assets that results from inflation. His acceptance of this adjustment demonstrates his strong commitment to the physical capital maintenance approach to income measurement even when calculating income attributable to proprietors.

It was this latter commitment that gave rise to his last serious public debate on price change accounting. In 1978, Peter Swan, then an economist at the Australian National University (and a son of T. W. Swan, who provided some of the models used in the earlier Mathews and Grant study), published a highly critical review of the Mathews Report's recommendations on business taxation. His criticisms were based upon a rigorous neoclassical economic model of the firm and this led him to advocate a general price level adjustment of opening capital, as in Ray Chambers' Continuously Contemporary Accounting (CoCoA) system (Swan, 1978: 9), although it was the capital maintenance model with which Swan was concerned, rather than the choice between current entry value (preferred by Mathews) and current exit value (preferred by Chambers). Thus, Swan rejected Mathews' physical capital maintenance concept, concluding that it represented 'an emotional crusade in which "business survival" has replaced the holy grail' (Swan, 1978: 13). Essentially, Swan's argument was that rising replacement costs did represent a gain to the firm if they could be passed on to the consumer, albeit that the gain might be reduced in real terms by a decline in the purchasing power of money (which would be captured by a general purchasing power adjustment). There would be no consequent financing problem, as visualised by the Mathews Report, if prices yielded sufficient expected profit to justify new investment: if necessary, such investment could be financed by the capital market.

A related criticism by $S$ wan was of the Mathews Report's failure to deal with monetary assets and liabilities properly. During periods of inflation, the so-called Fisher Effect produces a gain on borrowing or loss on holding monetary assets, which represents the difference between nominal and real interest rates (Swan, 1980: 270-271). This effect is most naturally expressed in terms of general price

\footnotetext{
59 The two will, of course. typically lead to the same result. The similarities between the recommendations of the Mathews Report and the Sandilands Report were possibly enhanced by contact between the two committees (Tweedie and Whittington, 1984: 80).
} 
level indices, because it is concerned with the purchasing power of money rather than the cost of a specific bundle of assets. The Mathews Report did not recommend any adjustment for this effect, and the only adjustment it considered to be possibly appropriate was the gearing adjustment.

Mathews' reply to Swan (Mathews, 1980) is instructive as an illustration of his underlying assumptions and objectives. He explicitly appealed to the methods of national income accounting ( $p$. 262) as authority for his approach of maintaining physical capital. He emphasised that 'the notion that under conditions of rapid inflation, a liquidity or cash flow problem is inherent in a system of historical cost accounting, pricing and taxation was central to the Committee's argument, and it is not possible to rebut it by asserting that the problem can be overcome by raising fresh capital' (p. 263). The latter was supported by an appeal to the depressed state of the capital market, which made it impossible for firms to raise additional funds. Equally, he questioned the practicality of firms being able to raise prices sufficiently to compensate for higher replacement costs if they were not given additional tax relief to reflect those costs. Finally, in response to the argument that appreciation in asset values constitutes a gain to proprietors, he wrote, 'it is difficult to conceive of any action which would be more damaging to the Australian economy and its competitive position than the inclusion in taxable income of the unrealised appreciation which has occurred in the depreciable assets held by business enterprises' (p. 267).

His reply to Swan shows that he approached the problem from the perspective of economic policy rather than economic theory. His reasoning was conducted within the practical constraints facing the policy-maker, and he assumed frictions and imperfections in the financial system which were inconsistent with Swan's theoretical model (p. 263). He was also concerned to construct a tax system that would work more effectively than the one in place, rather than attempting to achieve optimality, which he regarded as impractical. His concerns were as much macro-economic as micro-economic. The central concern of his Committee was "with the maintenance of financial stability in the business sector, with continuity of business investment and operations, in short with business survival' ( $p$. 263). In summary, Mathews adopted a Keynesian view of the economy, which regarded disequilibria and market imperfections as normal facts of economic life, creating a need for government intervention in order to correct them. ${ }^{60}$

Swan's rejoinder (Swan, 1980) re-iterated a number of points of logic which he felt that Mathews had not addressed, notably on the Fisher Effect, but the debate ended on a suitable note of agreement, in that both parties agreed that a proportional consumption tax would provide an effective and simple substitute for both the personal income tax and corporate profits tax (p. 276).

This exchange was Russell Mathews' final contribution to the price change accounting debate, and it illustrated both the strengths and the weaknesses of his current cost accounting model. These were explored further in the work of his pupil, Reg Gynther, to whom we now turn.

\subsection{Reg Gynther and the entity approach to price changes}

We have seen that Reg Gynther came late to academe, taking his first full-time academic post at the mature age of 37 . He acknowledged that his view of price change accounting was shaped by his practical experience as an accountant in business. This led him to adopt the 'entity' view of price change accounting, which is the perspective of the manager rather than of the shareholder or proprietor.

Like Mathews, Gynther produced a major work on price change accounting early in his research career. This was Accounting for Price-Level Changes: Theory and Procedures (Gynther, 1966). It was developed from his master's thesis for the University of Adelaide, and its central ideas were developed from an article published earlier in Accountancy (Gynther, 1962). This was supervised by Russell Mathews, and the assistance of both Mathews and Grant (as external examiner) is acknowledged in the preface. Thus, Mathews must have exercised some influence over the development of the work, despite the fact that the degree was taken on a part-time basis and at long distance (Mathews being based in Adelaide and Gynther in Brisbane). Certainly, the conclusions of the work, favouring specific replacement cost adjustments and rejecting the use of general price level indices, were consistent with the approach of Mathews and Grant. On the other hand, Reg Gynther was very much his own man, and he may have chosen his supervisor to match his well-developed interest in replacement cost accounting, which had developed from his commercial experience and his contact with the Philips system.

Whatever the origins of Gynther's interest in replacement cost accounting, his book (Gynther, 1966) became a standard source of reference on the methodology of replacement cost accounting, and it also contained most of the ideas that he developed further in his later work. Whereas Mathews and Grant's work had been concerned with aggregate adjustments to the accounts of the

\footnotetext{
${ }^{60}$ This view of Russell Mathews' economics was confirmed by an interview in August 2000 with Geoff Harcoun, emeritus professor of economics at Adelaide.
} 
company sector, using two simple adjustments and making a number of fairly heroic simplifying assumptions, Gynther was concerned with detailed replacement cost adjustment of the accounts of the individual company. He modelled his work on a study of the Philips system and, consistent with the approach of Limperg's Amsterdam School, was concerned that replacement costs should be recorded throughout the accounting system, as an aid to management as well as for external reporting purposes. Thus, the final four substantial chapters of his book (Chs 12 to 15 , inclusive) are devoted to matters of practical application (such as the choice between average and end of period prices, Ch. 12), including a case study of the application of current cost accounting in Philips Electrical Industries (Ch. 15). His book was shaped in two respects by his extensive practical experience in business. First, as we have already observed, his attachment to replacement cost arose out of his adoption of the perspective of the manager, rather than of the shareholder. Second, he approached the problem of replacement cost adjustment at the detailed level of the accounting system (illustrating many of his points by means of journal entries) rather than as a matter of adjusting the summary financial statements. In this respect he was a true accountant, like Chambers, with whom he was to debate strenuously on the relative merits of replacement costs and selling prices as the basis of valuation:

'It is believed that the main purpose of maintaining accounting records is to provide management with vital information to assist it in its day-to-day functions of planning, controlling and making decisions to increase the performances and efficiency of its entity'. (Gynther, 1966: 3)

The theoretical core of Gynther's work was based upon his entity perspective of the firm. He (like Mathews) was concerned with the preservation of the business entity (as expressed in an operating capability concept of capital maintenance) rather than with the maintenance of shareholders' wealth, in real or nominal terms. He expressed this perspective with admirable clarity and candour in his book, and this was one of his important contributions to the price change accounting debate, although a controversial one. Associated with this view was his belief in using specific prices, where possible, and, in their absence, specific indices, for the re-statement of accounts: 'The more specific the avaitable information is the better, and the more accurate the accounting will be as far as each firm is concerned' (Gynther, 1966: 55). This specific approach was to apply both to balance sheet valuations and to the restatement of opening capital:

'When the specific current cost of either an inventory item or a fixed asset item rises or falls, it costs more or less to be in that kind of industry. To treat any part of such a rise or fall as a profit or a loss is tantamount to looking at the rise or fall in prices through the eyes of a shareholder (or other outsider) and not from the viewpoint of the firm as a going concern'. (Gynther, 1966: 68)

He did, however, express approval of the work of Edwards and Bell (1961) and, perhaps as a concession to their approach, he accepted that it would be possible, although not desirable in the financial statements, to use general index adjustment of shareholders' funds, which would be offset against nominal holding gains and losses on real assets, to provide a measure of real holding gains, which could be added to profit 'for those with a general index concept of profit, i.e., for those with a proprietorship outlook' (Gynther, 1966: 81). However, he added a stern warning that, in his view, all such transfers to or from reserves should not affect the profit calculation but should instead be treated as appropriations of profit:

'Any such further transfers have nothing to do with the determining of profit itself. Such attempts to protect shareholders' funds are financing problems only'. (p. 81)

The specific index approach posed particular difficulties for the treatment of current monetary items. Gynther showed himself to be a pioneer of the 'monetary working capital adjustment', a feature of the current cost accounting (CCA) systems, which were later adopted by professional bodies:

'...the specific-index man treats as profits and losses the total movement (up or down) in the relative specific indexes that he associates with the monetary items'. (p. 139)

Thus, Gynther would apply to the net current working monetary asset pool (current assets less current liabilities) a specific index, related to the firm's purchasing pattern. In a period of rising prices, this would give rise to a loss, which would be an additional charge against profits, when net monetary assets were positive, and to a gain, which would add to profits, when net monetary assets were negative.

Long-term liabilities were treated differently from short-term liabilities in Gynther's approach. They were regarded as part of the permanent capital of the business, so that changes in their real value would, in effect, be transfers between bondholders and shareholders, which would not affect the total capital of the entity (p.151). Thus, Gynther's strict entity assumption ruled out his adoption of the gearing adjustment, which featured in some later CCA proposals.

A final feature of the book that is worthy of note is its comments on goodwill and intangible assets (pp.129-133). Here, Gynther not only foreshad- 
owed his own later paper on the subject (Gynther, 1969), but he also anticipated the approach adopted much later by the UK Accounting Standards Board (1997), which is also currently being considered by the International Accounting Standards Committee. He advocated capitalising purchased goodwill and writing it off only when it was impaired. He opposed compulsory amortisation. His reasoning was that, from his entity oriented view, the accounts should record a reduction in goodwill only when the operating capability of the business was impaired.

Gynther followed his book with a cycle of three papers on accounting for price changes, two in The Accounting Review (Gynther, 1967a and 1970) and one in Accounting and Business Research (1974). His paper on goodwill (Gynther 1969) was also published in The Accounting Review; so the period up to 1974 was the one in which he sought to address academic audiences at the highest level.

The cycle of papers on price change accounting elaborated on the ideas in the 1966 book but did not change them in any fundamental way. The first, on 'Accounting Concepts and Behavioral Hypotheses' (1967a), which built on an earlier paper (1962), explored the different assumptions and reasoning of advocates of both 'proprietary' and 'entity' theories of the firm. It showed considerable knowledge of the relevant literature and made an acknowledgement of social, political and psychological influences on accounting which, for its time, was incisive and anticipated later developments in the accounting literature. However, the conclusion was not novel: the author expressed his enthusiasm for the entity approach, based on his own experience:

'This author votes for the entity theory, and in so doing he admits that his twelve years in industry as an accountant-controller before entering academic life have shaped his frame of reference....' (Gynther, 1967a: 289)

The consequence of this was, of course, his operating capability concept of capital.

The second paper in the cycle, 'Capital Maintenance, Price Changes, and Profit Determination' (1970) elaborated on the alternative capital maintenance concepts and their consequences for profit measurement in price change accounting. It contained ( $p .720$ ) Gynther's matrix presentation of alternative price change accounting systems, with capital maintenance concepts identified in the rows and asset valuation methods in the columns, which he had previously published in a professional bulletin (Gynther, 1968: 13). There was also, in typical Gynther style, a substantial numerical appendix, enabling the accountant to see the detailed calculations and journal entries underlying the alternative systems. The main conclusion of the paper was that accounting for price changes is concerned with long term profit and that capital maintenance, rather than asset valuation, is fundamental to this process. He demonstrated this assertion by means of a numerical example which showed that errors in asset values ultimately reverse (as they are liquidated) whereas different capital maintenance concepts give rise to permanent differences in measured profit. Unlike most of Gynther's writings, this second paper did not reach a normative conclusion.

The final paper in the sequence (acknowledged as such by the author, Gynther, 1974: 141) was 'Why Use General Purchasing Power?' This focussed on an extensive discussion of the price indices, around the theme that these should be as specific as possible. Those used in accounts should be specific to the needs of the entity, and those used by the shareholder should be specific to the consumption pattern of the individual shareholder. Hence, the author opposed the use of general price level indices in the accounts: the place of a general price level adjustment was in the personal accounts of the proprietor (or shareholder), and the index should be selected according to the needs of the individual. This was, of course, an elaboration of another of Gynther's themes: its genesis owed a great deal to the work of Hendriksen (1961 and 1963), which were cited extensively in Gynther (1966). The paper also contained an interesting appendix (Appendix 2), which elaborated the matrix treatment of asset valuation and capital maintenance, attributing various combinations to various authors. It shows Gynther's 'ideal concept' (i.e., not practical) of capital maintenance as being Net Present Value. This is consistent with his discussion of asset valuation in his 1970 paper and also with his paper on goodwill ('Some "Conceptualizing" on Goodwill', 1969). The latter paper had elaborated the earlier goodwill proposals in Gynther (1966) and made clear that the author preferred the capitalisation and revaluation on a net present value basis (i.e., what would now be known as an 'impairment test') of purchased goodwill but would also, ideally, treat self-generated goodwill on this basis. Thus, his ideal balance sheet would show specific assets at replacement costs, but goodwill at net present value, the total summing to management's estimate of the total net present value of the business. However, Gynther rejected the view that goodwill is simply a residual amount, representing the present value of expected abnormal returns. He took the view that such returns had a source, albeit an intangible one, and that is why it should be amortised only when the source was impaired.

The 1974 paper completed the elaboration of the ideas that Gynther had developed in his 1966 work. Having, in effect, completed his programme 
of academic research, he moved in 1977 to the accounting profession. This gave him the opportunity to apply his ideas through his influence on the accounting standard-setting process. He had always sought to make his work practical and accessible to practitioners, through publication in professional journals. One of these publications led to a controversy with Chambers, to which we will return.

His new role as research partner of a leading professional firm enabled Gynther to continue his crusade through publication in professional journals but also gave him greater access to the standardsetting process. He therefore had a considerable influence on the development of a current cost accounting standard in Australia (Tweedie and Whittington, 1984: Chapter 8). Notably, he contributed to the debate on the treatment of monetary items and was a member of the committee that produced the 1978 exposure draft (Australian Accounting Research Foundation, 1978), which proposed specific indexation of the net monetary asset pool, with no adjustment for long-term liabilities. This was almost a replica of Gynther's conclusions in his previous work. Statement of Accounting Practice 1, Current Cost Accounting (Australian Society of Accountants, 1983) which was the ultimate outcome of the Australian standard-setting debate, incorporated the monetary working capital adjustment and relegated the gearing adjustment (for long-term debt) 'below the line', as Gynther would have wished.

At this stage (1983), it must have seemed that Reg Gynther's move to the accounting profession had resulted, in practical terms (which is what he would have valued), in triumph over his old adversary, Ray Chambers, who advocated a very different price change accounting system, Continuously Contemporary Accounting $(\mathrm{CoCoA})$ : asset values based on selling prices, combined with a capital maintenance concept of the proprietorship type, based on general index adjustment. However, as we have seen, the triumph was shortlived. The 1983 statement was a recommendation rather than a standard, and it was not widely followed. As inflation rates fell and industry (in the absence of the concessions based on it) rebelled against CCA, this system of accounting failed to take root in Australia or elsewhere (Tweedie and Whittington, 1997).

We now turn to consider the creator of the CoCoA system, Ray Chambers.

\subsection{Ray Chambers and Continuously Contemporary Accounting ( $C o C o A$ )}

As we have already seen, Ray Chambers devoted most of his long career to the academic study of accounting, unlike Russell Mathews, the majority of whose publications was in the public finance area, or Reg Gynther, who came late to academe from commerce and left early to take a partnership in a professional firm. Thus, in dealing with Ray Chambers' contribution to price change accounting, we are touching on only a small part of his contribution to accounting thought and the academic literature of the subject.

Nevertheless, accounting for price changes was an important aspect of his theory of Continuously Contemporary Accounting ( $\mathrm{CoCoA})$, developed in his most important work, Accounting, Evaluation and Economic Behavior (AEEB) (1966b). We therefore have to understand the development of $\mathrm{CoCoA}$ in order to understand his views on price changes.

Chambers was driven by a desire to develop accounting theory on what he called a scientific basis. By this, he meant that the theory should be logically deduced from clearly stated assumptions - i.e., it should be deductive, as opposed to the inductive approach of his predecessors, such as Littleton (1953), who had observed accounting practice and attempted to rationalise it. In this endeavour, he was inspired by the work of Canning (1929) who had observed the primitive state of accounting theory from the perspective of an economist. This agenda was spelled out in Chambers' 'Blueprint for a Theory of Accounting' (1955a).

The next major development was in Towards a General Theory of Accounting (1961), which presented 40 basic assumptions and derived 21 principles from them. With regard to price changes, Chambers stressed the importance of stating the financial position at balance sheet date properly. He therefore advocated the valuation of assets at their current values as measured by replacement prices: ${ }^{61}$

'Replacement price (or replacement cost) does not mean some hypothetical future price to be paid on some hypothetical future replacement date. It means the price currently ruling for equivalent service potential. The price currently ruling for producers' goods is the market's assessment of expected income flows from their use at the present level of prices, for all potential users of such goods.' (Chambers, 1955: 29, para. 90)

Later, he was to modify this view and he conducted a crusade in favour of selling prices rather than replacement costs.

Another feature of the 1961 paper was Chambers' treatment of changes in the general price level. His earlier professional writings had recognised the problem of changes in the general price level affecting the value of the unit of measurement

\footnotetext{
${ }^{61}$ He had first advocated replacement cost accounting adjustments much earlier in a brief paper (Chambers, 1949) that might have won the applause of Mathews and Gynther.
} 
(money), as being distinct from the problem of changes in specific replacement prices (e.g., Chambers, 1952b, in which he cited Sweeney, 1936). In his 1961 study, he formalised this in his celebrated notation, which became almost a standard in the literature for expounding alternative models of price change accounting. ${ }^{62}$ Starting with a balance sheet, defined as:

$\mathrm{M}+\mathrm{N}=\mathrm{L}+\mathrm{R} \ldots$. .

(where $\mathrm{M}$ are Monetary Assets, $\mathrm{N}$ non-monetary assets, $L$ liabilities and $R$ residual equity),

he multiplied through by the change in the general price level $(1+p)$ over a period which was otherwise transactionless, to yield (Chambers, 1961: 35):

$$
\begin{aligned}
& \mathrm{M}(1+\mathrm{p})+\mathrm{N}(1+\mathrm{p})=\mathrm{L}(\mathrm{l}+\mathrm{p}) \\
& +\mathrm{R}(1+\mathrm{p}) \ldots .
\end{aligned}
$$

And, remembering that the monetary items, $M$ and $\mathrm{L}$, are, by definition, fixed in monetary terms, this led to the conclusion that, if $\mathrm{p}$ were positive, there would be a loss on holding money of $\mathrm{pM}$ and a gain on borrowing of $\mathrm{pL}$, although at this stage Chambers did not treat such gains and losses as part of profit. This simple statement, which is now so familiar as to seem obvious, was, at the time, a considerable clarification of the issue. It led Chambers to take a proprietary view of capital and to support the use of general purchasing power indices for capital maintenance purposes, an issue that he later clarified through modification of his notation (Chambers, 1967b). This brought him into direct conflict with Russell Mathews, in a heated, published debate which we shall review later. The issue there was the role of general indices and the treatment of monetary items, but Ray Chambers was about to enter a more momentous debate, that relating to valuation, which lasted for the rest of his career.

The valuation issue was clarified, and, in Chambers' view, settled, in $A E E B$ (1966b), which developed his 1961 framework into a comprehensive theory of financial accounting, Continuously Contemporary Accounting ( $\mathrm{CoCoA})$. The anchor of this system was its valuation principle of current cash equivalent, by which Chambers meant realisable values. Thus, he had switched allegiance from buying prices (replacement costs) to selling prices. He modified this in the case of work-inprogress inventories and non-vendible durables (i.e., fixed assets with little or no resale value which were nevertheless assets that were essential to the business) by allowing replacement cost to be used a proxy for current cash equivalents in such cases. When his critics gleefully seized on this as an inconsistency, Chambers, who was fastidious (even relentless) in his application of logic, changed his position to one that he regarded as being totally consistent: if work-in-progress and non-vendible durables had no sale price, then they would be given a zero value (Chambers, 1970).

Chambers' conversion to selling prices was driven by the logic of his theoretical assumptions. It was foreshadowed in his paper 'Measurement in Accounting', published in 1965 but first drafted in 1963. Two particularly pregnant excerpts from the introduction to this paper are as follows:

'It transpires that the assumption of adaptive behaviour in a changing environment necessitates a set of quantification rules which shall be a measurement system.' (Chambers, 1965d: 32)

and

'This paper takes uncompromisingly the position that accounting is concerned strictly with the past and present, but so that it is always relevant to the future. To mix measurements with expectations is to confuse an already complicated present. To make measurements is the business of the accountant as such; to form expectations is the business of actors.' (p. 33)

These quotations capture the essence of Chambers' thought, although from that essence he generated a complex system. The first quotation indicates that he was concerned with adaptive behaviour, and that he wished to develop a measurement system around this objective. His idea of a measurement system would be one that was comprehensive and logically consistent. The second quotation indicates that he was concerned to provide information that was as up-to-date as possible without straying into assumptions or expectations about future actions. In a way, this showed him to be a true accountant, because he was concerned with events that have occurred, rather than ones that might occur; i.e., he wished to report ex post rather than ex ante. However, because he was concerned with adaptability, he wished to reflect the current financial position, and this led him to current values rather than historical cost. He preferred current cash equivalents, based on selling prices, rather than replacement costs, because, in order to adapt, the entity would have to realise its assets as a pre-condition. Thus, selling prices were always potentially relevant. Moreover, they reflected an aspect of the entity's present holding of assets, unlike replacement costs, which represented the cost of assets that the firm had not yet acquired, even if it might expect to do so in the future.

$A E E B$ was a remarkable work of scholarship, showing encyclopaedic knowledge, extending far beyond accounting, and it made an ambitious attempt to provide a new, rigorous, framework for accounting, the scope of which is wider than our

${ }^{62} \mathrm{He}$ later reviewed these applications in Chambers (1978b). 
present review. The heart of the CoCoA system is developed in four chapters (4. Monetary Calculation, 5. Financial Position, 9. Trading Ventures, and 10. Accounting for Trading Ventures) out of a total of 14. Stripped of all the supporting arguments, these chapters basically advocate a valuation system based on resale prices ('current cash equivalents'), using the arguments from Chambers (1965d), summarised above, and combined with general price level adjustment of proprietors' equity, to allow for changes through time in the value of the monetary unit of measurement, as developed in Chambers (1961) and (1965c). Thus, Chambers supported the broad system adopted earlier by Edwards and Bell (1961), but with the important exception that he deplored Edwards and Bell's acceptance of replacement cost as the method of valuation in their business profit model. He asserted that:

'In relation to adaptive behaviour the relevant price of goods in possession, their opportunity cost, is the present market resale price'. (Chambers, 1966b: 201)

He saw replacement cost as being related to the replacement decision, but that was a matter for future action rather than the measurement of the present financial position (p. 202). Equally, he rejected, for accounting purposes, the use of discounted present values of assets currently held, because these involved expectations about the future, whereas he was concerned with opportunities available in the present: ${ }^{63}$

'Whatever consideration one gives to the longrun, adaptation in a fluid environment cannot be deferred. Adaptation is action here and now.'

and

'The process of determining financial position, the accounting process, can take no cognisance of expectations in respect of the long- or shortruns. Until the manager of a firm discovers its present position, he does not know whether he is able to take a long-run view or must be content with short-run adaptation.' (p. 205)

These strongly expressed views naturally led to considerable controversy on the valuation question, particularly with advocates of the 'value to the business' method (sometimes known as deprival value), such as Baxter (1967), Solomons (1966) and Wright (1966). Value to the business is based on what Chambers would have called 'longrun' considerations, based on the going concern assumption and using discounting methods as one component of the assessment of value. At the heart of the issue was Chambers' refusal to accept that values based on expectations are suitable for inclusion in accounts, and his assertion that current cash equivalents contained no element of expectation (although cash realisation is a future event).

Chambers answered these critics in his 'Second Thoughts' paper (1970). This was in many respects his definitive statement on $\mathrm{CoCoA}$. We have already seen that, in this paper, (pp. 47-49), he hardened his views on valuation by excluding replacement costs as proxies for the selling prices of work-in-progress and non-vendible durables. He also acknowledged (p. 43) that he had been wrong to use the idea of realisation in his discussion of the relation between inventory values and income: recognition in the CoCoA system depended only on asset prices changing, not on sale of the asset.

Apart from these two concessions, Chambers held his ground with robust arguments, and he continued to do so for the rest of his life. His arguments against 'value to the business' (Chambers 1970: 44-47) are a good illustration of his confrontational debating style. His numerical example (p. 46) shows clearly that he was concerned with the opportunities offered by the cash represented by the asset, whereas his opponents were concerned with the opportunities offered by ownership of the asset itself (including discounted present value). Both seem to be legitimate things to be interested in, but when, as a compromise solution, Reg Gynther (1971) later suggested multiple column reporting, he was, as we shall see, roundly criticised, as someone who was, from a CoCoA perspective, a heretic. This numerical example is also of interest because of its implicit assumption of capital rationing: in his two 'feasible' cases, case (a) and case (b), it is assumed that an asset with a present value in excess of resale price should be sold and reinvested in a new asset, if the present value of the new asset is higher. If the firm could raise more funds at its cost of capital, it should clearly, in this case, invest in both assets. By assuming that resale prices of existing assets constrain investment opportunities, Chambers was here making an implicit assumption of capital market imperfection which, strangely, also lay behind Russell Mathews' belief that holding gains could not be regarded as part of profit (as revealed in his debate with Swan).

Another contentious issue was that of long-term liabilities, which Chambers (1966b) had insisted should be recorded at face value, rather than at market value, despite the fact that similar bonds held as assets would be recorded at selling prices. $\mathrm{He}$ defended this in his 'Second Thoughts' (Chambers, 1970: 158-159) and later in his 'Third

\footnotetext{
${ }^{63}$ Barton (2000b) attempts to reconcile the exit and entry value approaches by suggesting that the former is concerned primarily with the short run and the latter with the long run. These extracts from Chambers' work are consistent with this
} view. 
Thoughts' (Chambers 1974b: 132-134), using the argument that long-term liabilities are somehow similar to equity claims:

'The position is perhaps analogous to that of stockholders'. (Chambers, 1970: 50)

Here again, there is a remarkable resemblance to the assumptions of his opponents, such as Mathews (who refused to recognise an inflationary 'gain on borrowing', on similar grounds) and Gynther (whose 'entity' approach precluded 'gains' arising from transfers between long-term debt and equity).

After the 'Second Thoughts', Chambers devoted himself vigorously to the defence of his system against its critics (e.g., Chambers, 1976d, whose title captures his contentious style: 'Continuously Contemporary Accounting: Misunderstandings and Misrepresentations'), in promoting it as a suitable system for adoption by accounting standardsetters (e.g., Chambers, 1980), in gathering relevant empirical evidence (Chambers, 1973), and in demonstrating how the system could be applied in particular aspects of accounting practice (e.g., Chambers, 1983). He remained fiercely critical of the "value to the business' method, and of many of the efforts of accounting standard setters which, in his view, lacked an adequate conceptual basis (Chambers, 1998). Thus, he devoted the remainder of his career to fulfilling the task he had set in 1966:

'We have not come to the end of the road. In a very real sense, much of the journey lies ahead. Only the broadest questions have been broached, and perhaps not all of those. To the minutiae of everyday transactions, and their treatment in accounting, little attention has been given'. (Chambers, 1966b: 365)

We now turn to consideration of two published interchanges on the issue of accounting for price changes that took place between Ray Chambers and our other two subjects, Russell Mathews and Reg Gynther, respectively.

\section{Two interchanges}

5.I. Chambers v. Mathews on general price level adjustment

We have already noted that, in 1965, Russell Mathews published a highly critical review of ARS 6, the American research study which advocated general price level adjustment of historical cost accounts (often known as Current Purchasing Power, or CPP Accounting) as the appropriate response to inflation. His central criticism was that current valuation is an essential requirement for accounts to meet the requirement of reporting changing prices. The valuation of assets at historical cost, adjusted by subsequent changes in the general price level was regarded as 'useless': what was required was an adjustment with respect to the specific prices of the asset concerned.

Chambers did not disagree with Mathews' analysis up to this stage, although Mathews' idea of a specific price was a replacement price, whereas Chambers had just undergone his conversion to the CoCoA method, which used selling prices as the basis. Their disagreement arose in relation to the capital maintenance concept: Mathews, in his critique, used his preferred 'entity' concept, based on replacement costs and refused to include gains on borrowing or losses on holding money in the calculation of profit. Thus, he did not recognise general price level adjustments of capital as affecting profit calculation within the accounting period: for him, as for the national income accountant, the main purpose of general price level adjustment was to facilitate comparisons between accounting periods and was therefore 'of relatively minor significance' (Mathews, 1965a: 137).

From Chambers' perspective, Mathews added insult to injury by borrowing (or, as Chambers was later to describe it, mis-using) Chambers' own notation to support his case. Chambers (1961: 35) had derived from (1) and (2) above the following expression:

$$
\begin{aligned}
& \mathrm{M}+\mathrm{N}(\mathrm{l}+\mathrm{p})=\mathrm{L}+[\mathrm{R}(\mathrm{l}+\mathrm{p}) \\
& +\mathrm{Lp}-\mathrm{Mp}] \ldots
\end{aligned}
$$

This expression groups, in the square brackets, the adjustments for monetary items together with residual equity. Chambers also noted that

$$
\mathrm{pN}=\mathrm{pR}+\mathrm{pL}-\mathrm{pM} \ldots
$$

Thus, the 'p' multiples in the square brackets were equivalent to the price adjustment of nonmonetary assets. Although, as a piece of algebra, this is identically true, Chambers subsequently considered the exposition to be misleading from an accounting perspective (Chambers, $1965 \mathrm{c}$ and 1978b):

'the deceptive simplicity of the assumptions led me into error' (Chambers, 1965c: 244).

There were two key simplifications. First, the grouping of the monetary adjustments (pL and pM) with residual equity, $R$, is obviously algebraically possible, but it wrongly (from Chambers' proprietary perspective) assumes that the monetary adjustments are made direct to capital rather than appearing as separate gains or losses to be reported in the profit and loss account. Second, the example did not allow for specific price adjustments of the non-monetary assets, $N$, to give rise to real holding gains and losses on these items: such gains and losses were, from Chambers' perspective, part of the total profit of the period, not simply adjustments to capital. 
To Mathews, however, the implications of Chambers' assumptions were entirely acceptable. Under his physical capital maintenance concept, real holding gains or losses on non-monetary assets and gains or losses on monetary items were excluded from profit, and he quoted Chambers' result ((4), above) with approval (Mathews, 1965a: 139-140). This use of Chambers' notation enabled Mathews to claim that his preferred system (recording only specific price changes) embraced general price level adjustment. This was true only in the unusual case in which the specific price changes were the same as the change in the general price level, and if it were considered appropriate to regard gains and losses on monetary items as adjustments to capital rather than as part of profit.

Chambers $(1965 \mathrm{c})$ responded vigorously to Mathews' use, or mis-use, of his notation. As we have seen, he realised that he had previously (Chambers, 1961) failed to recognise the simplifying assumptions underlying his notation, particularly in his derivation of (4), above. He developed a more general model, in which the specific price of non-monetary assets, $\mathrm{N}$, changes at a different rate, $\mathbf{r}$, from that of the general price level, $\mathrm{p}$, and in which holding gains and losses are separated from capital adjustments. Thus, (3) above was replaced by:

$$
\begin{aligned}
& \mathrm{M}+\mathrm{N}(1+r)=\mathrm{R}(1+\mathrm{p})+\mathrm{N}(\mathrm{r}-\mathrm{p})-\mathrm{Mp} \\
& \text { and income included the holding gains: } \\
& \text { Income }=\mathrm{N}(\mathbf{r}-\mathrm{p})-\mathrm{Mp} \\
& \text { (Chambers, 1965c, p.244) }
\end{aligned}
$$

This was consistent with Chambers' proprietary approach to capital maintenance, combined with current valuation of assets. It can be contrasted with Mathews' preferred approach (1965a: 140), which was:

$$
\mathrm{M}+\mathrm{N}(\mathbf{l}+\mathbf{r})=\mathrm{R}+\mathrm{Nr}
$$

This yielded (in a transactionless period) a zero measure of income, because holding gains and losses went directly to capital (through $\mathrm{Nr}$ ).

Not content with criticising the use of his own notation, Chambers (1965c) made a searching examination of the assumptions underlying Mathews' physical capital maintenance/replacement cost system, and particularly the effective exclusion from Mathews' income calculations of gains or losses due to a change in the purchasing power of money:

'And are we to suppose that when a firm sells a good the money it receives is specialised money only fit for doing specialised things?' Chambers, 1965c: 249)

Inevitably, Chambers' vigorous critique attracted a response from Mathews (1967), who saw the central point but found it hard to resist being drawn by Chambers' disputatious style:

'To a large extent the differences between us are differences of definition although Chambers also charges me with an error of logic....' (Mathews, 1967: 113$)^{65}$

After restating his own current value assumptions, and stating (correctly) that this was not logically incomplete, within its own assumptions, Mathews came to the central point:

'My chief criticism of the model is concerned with its treatment of $\mathrm{N}(\mathrm{r}-\mathrm{p})-\mathrm{Mp}$ as income; Chambers would be prepared to distribute $\mathrm{Nr}$, as income, except to the extent that a purchasing power loss $\mathrm{Rp}$ (that is, $\mathrm{Np}+\mathrm{Mp}$ ) has occurred on opening residual equity. But although the distribution of $\mathrm{N}(\mathrm{r}-\mathrm{p})-\mathrm{Mp}$ (or $\mathrm{Nr}-\mathrm{Rp}$ ) will leave the firm with a residual equity that is maintained in terms of general purchasing power, this will not, to the extent that $\mathrm{Nr}$ exceeds $\mathrm{Rp}$, command the same quantity of operating assets $\mathrm{N}$ at their new prices $\mathrm{N}(1+$ r).' (Mathews, 1967: 116)

Thus, the essential difference between the two protagonists was one of assumption about the appropriate capital maintenance concept. This might have been an appropriate note on which to end the debate, but there was yet another response from Chambers.

Chambers' response (1967b) offered 'an improved representation' of his notation, as well as some further criticisms of Mathews' concept of capital maintenance. With respect to the latter, he shrewdly pointed out (pp. 215-216) the difference in perspective of national income accounting (to which Mathews' approach was well suited) and business accounting. ${ }^{66} \mathrm{In}$ the new exposition of his notation, he introduced currency symbols, with different symbols representing the value of the currency unit at different times. This particular innovation did not find favour with subsequent authors, such as Parker and Harcourt (1969) and Barton (1977), who preferred using time subscripts to indicate the point in time at which the

\footnotetext{
${ }^{64}$ There is no trading income in this model because, for simplicity, a transactionless period was assumed. $M$ now has $L$ netted off against it, so that it is equivalent to $M-L$ in the previous notation.

${ }^{65}$ He goes on to refer to a dispute about the averaging procedure for price adjustment, which was raised by Chambers $(1965 \mathrm{c})$. This dispute is not discussed here because it was not central to the differences between them and is essentially concerned with technique rather than principle.

${ }^{66}$ One of the founders of the current cost accounting, Schmidt (1931), explicitly expressed the argument for a physical capital maintenance concept in the context of preserving the productive capability of the nation, although Chambers seems to have been unaware of this at the time. Schmidt is not referred to in $A E E B$.
} 
currency unit was dated. They were roundly criticised for their alleged 'abuse' of the notation in Chambers (1978b).

The interchange ended with a very brief 'rejoinder' from Mathews (1968) in which he re-stated his position and defended his physical capital maintenance concept as follows:

'The weakening of the firm's financial position is a fundamental objection, not only to Chambers' system but to any other approach... which defines income in such a way as to allow for the differential effects of general and specific price changes'. (Mathews, 1968: 285)

He did not explain the assumptions that lay behind the view that maintenance of real financial capital, as advocated by Chambers, would lead to a 'weakening of the firm's financial position'. Some of these were aired in his later debate with Swan, which we have already reviewed.

The net outcome of the debate was that both parties clarified their positions, and their fundamental differences of assumption became more obvious. Also, Chambers changed his position on an important issue, capital maintenance (now recognising monetary gains and losses in profits). In later years, he was more inclined to defend his position than change it.

\subsection{Chambers v. Gynther on multiple column reporting}

In December 1971, Reg Gynther published a paper, 'Accounting for Changing Prices: Some Recent Thinking, Recommendations and Practice', in The Chartered Accountant in Australia. The paper drew attention to the recent rises in the rate of inflation in Australia and elsewhere, and illustrated its distortionary effects on conventional historical cost profits. He also reviewed various proposals for dealing with the problem, suggested by academics and by professional bodies. He explained clearly the alternative models that had been suggested, with numerical examples, and he emphasised a theme that ran through his other writings: the importance of the capital maintenance concept in measuring income. His exposition of the capital maintenance issue was, in fact, much clearer than that of either Chambers or Mathews in their interchange described above. He also emphasised the importance of using current asset values rather than historical cost adjusted by a general index (the latter having recently been favoured in pronouncements by professional bodies in the UK, and the US). He concluded by commending the Philips system, explaining the usefulness of a similar system in a company of which he was chairman, and criticising the piecemeal approach to price change adjustment.

In general, Gynther's argument was a clear, live- ly and persuasive exposition of an emerging problem and of alternative solutions to it. For example, although he made clear his own replacement cost preferences, Gynther provided a very fair exposition of Chambers' CoCoA system. He also recognised that different types of information could be relevant to different users, and, rather than insisting on replacement cost as the only method, made the following suggestion:

'The solution could quite easily be the production of multiple column statements in which the results of several of the combinations of (i) net asset valuation methods and (ii) capital maintenance ideas are presented.' (Gynther, 1971: 19)

A brief paper by another academic, Philip Brown (1971), followed Gynther's and supported the usefulness of multiple column reports.

It might have been expected that Ray Chambers would have supported much of what Gynther wrote, especially the emphasis on the misleading nature of historical cost accounts in periods of inflation, the critical importance of current values (rather than indexed historical cost) and the distinction between asset valuation and capital maintenance. However, Chambers (1972a) responded with an all-out attack on Gynther. The issue that particularly provoked Chambers was the brief paragraph, quoted above, which suggested the possibility of multi-column statements. Chambers described this as 'a flanking attack' (p. 4) and asserted that multiple column statements were 'a weak conclusion' which would lead to confusion. He then, in a paragraph significantly prefaced 'I believe', asserted the importance of precisely identifying financial position, with the clear implication that his CoCoA method was the only means of doing this. He went on to describe:

'The result - uncertainty and confusion, to the extent of what has been called "scientific scanda]"'. (Chambers, 1972a: 5; footnote omitted)

Chambers then proceeded to outline his own assumptions about accounting, and asserted that the alternative systems, described by Gynther (other than $\operatorname{CoCoA}$ ), would not meet them. He then launched into an attack on Brown's assertion that multiple column reporting would provide data for empirical research on the usefulness of alternative measures. In doing this, he asserted that:

'One of the most elementary rules of enquiry is to isolate causal factors, and not to mix them up or apply them simultaneously in the course of enquiries made to isolate their several effects.' (Chambers, 1972a: 8)

This statement shows a lack of appreciation of the efforts of econometricians and other social science researchers, who have striven to develop sta- 
tistical methods to model situations where several causal factors work simultaneously. Of course, controlled experiments would be a much simpler and more efficient research method, but the real world does not often give such opportunities to social scientists.

Chambers concluded with a section ("Cui Bono?') in which he described calls for investor decision-making as 'a red-herring' and called for an end to 'sterile argument and invention'. In case his displeasure had not been adequately expressed, he concluded by repeating the allegation of 'an intellectual scandal'.

Not surprisingly, Gynther, who was not usually at a loss for words, appeared to be taken aback by this verbal assautt and replied briefly in the form of a letter (Gynther, 1972). In this, he deplored Chambers' 'irritating' writing style and 'unreasonable comments' and described the allegation of 'an intellectual scandal' as 'offensive' (p. 42). He explained the essentially didactic objective of his paper (which he had fulfilled admirably) and concluded that "the "tirades" by Chambers tend to become wearisome to many people' (p. 42).

This ended the exchange between Chambers and Gynther, but the cause was taken up, on Gynther's behalf, by Edward Stamp (Stamp, 1972). With characteristic eloquence and wit, he destroyed Chambers' analogies with locating the position of a ship and the methods of the natural sciences (as a natural science graduate who had served in the Canadian Navy, he was well qualified to comment on both), and made a powerful case that accounting should not be 'one-eyed' (p. 12). The response from Chambers (1972c) was perhaps predictable: a strong defence of $\mathrm{CoCOA}$ but little direct response to Stamp's arguments for a multi-dimensional approach.

This debate is perhaps of most interest for the light that it sheds on Ray Chambers' evolving attitudes. In his early debate with Mathews, he had offered considerable insight into Mathews' own thoughts, and he had modified his own. After the publication of his major work in 1966, and even more after his 'Second Thoughts' (1970), he seems to have regarded his system as complete and to have decided to defend it vigorously against all comers. He may also have been disappointed by the sceptical reaction of several commentators on his 1966 book, to whom his 'Second Thoughts' was addressed.

Too much significance should not be read into the gladiatorial style of the debate. This was characteristic of Chambers when defending CoCoA (or indeed any intellectual position), but it did not extend to personal animosity. Outside the debating arena, he had particularly good personal relationships with Russell Mathews and Eddie Stamp, both of whom wrote warmly of their respect for him in the volume of Abacus (dated December 1982) that marked Chambers' retirement. However, the style of the debate may have had adverse consequences for the reception of Chambers' own views both in the accounting profession and in academe.

In the accounting profession, the issue of inflation accounting was becoming very important in the early 1970s, as inflation gathered pace. Academics such as Mathews, Gynther and Chambers were agreed on many issues, and notably on the need for some form of current valuation, as opposed to general indexation of historical costs. The main choice of model lay between CCA (which embodied one version of the former) and CPP (which embodied the latter). Gynther's (1971) liberal proposals would have enabled these academics to take a united front on the need for current values. Instead, Chambers' strong dissent enabled unsympathetic practitioners to argue that 'the academics cannot even agree amongst themselves'. Thus, Chambers' 1972 intervention, and the attitude that it represented, may have resulted in precisely the 'weak' message from academe that he was trying to avoid.

In academe, there was increasing impatience with an apparently sterile debate between "normative' theorists who insisted that others were wrong merely because they made different assumptions. This mood of impatience was well captured in an influential paper by Carl Nelson (1973), and it was associated with an increased interest in assessing alternative accounting methods empirically through statistical studies, such as stock market impact studies, which had been pioneered by young researchers such as Beaver (1968) and Ball and Brown (1968). Later, Watts and Zimmerman (1979) took this a stage further by reducing the status of 'normative' theorising (as done by Mathews, Gynther and Chambers) to that of providing 'excuses' for people to choose accounting methods which suited their own interests. These developments were probably inevitable, in the light of changing technologies (databases and computing power became more accessible) and the natural tendency of new generations to seek new methods, but the process was possibly encouraged by the confrontational and unconstructive style of debate between such 'normative' theorists.

\section{An overview}

Mathews, Gynther and Chambers all served to clarify the issues of price change accounting, particularly in the three decades from the early $1950 \mathrm{~s}$ to the late $1970 \mathrm{~s}$, when the subject attained increasing importance on the agendas of practical policy-makers. The subject itself receded in prominence and importance as inflation subsided (Tweedie and Whittington, 1997), but the issue of 
price changes remains fundamental to accounting measurement, as do the associated issues raised by price change accounting. Thus, for example, international groups of standard-setters are currently wrestling with the restructuring of the income statement. This raises many issues, such as the appropriate concept of capital maintenance, the criteria for income recognition, and the relationship of the profit and loss account to the balance sheet, which were clarified in the earlier debates. The concept of financial adaptability, on which Chambers laid such stress, has also entered the consideration of accounting standard setters (e.g., Accounting Standards Board 1999: 28). Equally, in academic research, the work of Ohlson (1995) and Feltham and Ohlson (1995) has revived interest in the theoretical relationship between accounting information and stock market valuation, and particularly the implications of the 'biased accounting' to which traditional historical cost accounting often gives rise.

Thus, the work of our trio in price change accounting and accounting theory generally has added to the stock of knowledge. However, their contribution was much wider than this. We have already alluded to Mathews' substantial work in public finance, Chambers' much wider contribution to accounting, and Gynther's professional work. The major contribution of all three was to increase the rigour and status of accounting as an academic discipline. In Mathews' case, this is apparent not only in his research, but also in his textbook, Accounting for Economists (1962), which sought to improve the application of economics to accounting and the intelligibility of accounting to economists. In Chambers' case, it was most apparent in $A E E B$ (1966), which was a truly remarkable and innovative attempt to derive a comprehensive accounting system from a set of axioms. In Gynther's case, his academic output shows an eloquence, clarity of thought and curiosity which is all the more remarkable, because, unlike the other two, he did not have the advantage of completing an undergraduate degree before he became an academic. In all three cases, the contribution was crowned by founding distinguished academic departments: Mathews in Adelaide and the Australian National University, Gynther in Queensland, and Chambers in Sydney.

In summary, Mathews, Gynther and Chambers, each in his distinctive way, made a lasting contribution to accounting thought and education. They were fortunate in living at a time when there was an obvious need for their contributions, but they seized their opportunities and thus earned their place in accounting history.

\section{References}

AAANZ Outstanding Contribution to the Accounting Research Literature Award' (1996). AAANZ Newsletter, 3 (Winter): 8, 12 .

Accounting Standards Board (1997). Goodwill and Intangible Assets. Financial Reporting Standard 10. London: ASB.

Accounting Standards Board (1999). Statement of Principles for Financial Reporting. Revised exposure draft. London: ASB.

Australian Accounting Research Foundation (1978). The Recognition of Gains and Losses on Holding Monetary Resources in the Context of Current Cost Accounting. Exposure draft. Melbourne: AARF.

Australian Society of Accountants and the Institute of Chartered Accountants in Australia (1983). Current Cost Accounting. Statement of Accounting Practice I. Melbourne: ASA and ICAA.

Ball, R. and Brown, P. (1968). 'An empirical evaluation of accounting income numbers'. Joumal of Accounting Research, 6 (Autumn): 158-178.

Barton, A. (1977). The Anatomy of Accouming (2nd edition). St. Lucia, Qld.: University of Queensland Press.

Barton, A. (2000a). 'Vale to Russell Mathews, CBE, AO'. AAANZ Newsletter, 7 (March): 10.

Barton, A. (2000b). 'Reflections of an Australian contemporary: the complementarity of entry and exit price current value accounting systems'. Abacus, 36 (October): 298-312.

Baxter, W. (1967). 'Accounting values: sale price versus replacement cost'. Journal of Accounting Research, 5 (Autumn): 208-214.

Beaver, W. (1968). 'The information content of annual eamings announcements'. Joumal of Accounting Research, 6 (Supplement): 67-92.

Benston, G. (1967). Review of Accounting, Evaluation and Economic Behavior. The American Economic Review, 57 (March): 297-299.

Brown, P. (1971). 'Accounting for changing prices: a comment'. The Chartered Accountant in Atstralia, 42 (December): 24-25.

Brown, R. (1982). 'Raymond John Chambers: a biogra. phy'. Abacus, 18 (December): 99-105.

Buckley, J., Kircher, P. and Mathews, R. (1968). 'Methodology in accounting theory'. The Accounting Review, 43 (April): 274-283.

Burrows, G. (1989). 'Glimpses of A. A. Fitzgerald' in Kert, J. and Clift, R. (eds.), Essays in Honour of Louis Goldberg: 277-295. Melbourne: Department of Accounting and Business Law, University of Melbourne. Burrows, G. (1996). The Foundation: A History of the Australian Accotming Research Foundation 1966-91. Caulfield, Vic.: Australian Accounting Research Foundation.

Canning, J. (1929). The Economics of Accouttancy: A Critical Analysis of Accounting Theory. New York: The Ronald Press Company.

Carson, A. B. (1958). The Public Accounting Profession in California. Los Angeles: Bureau of Business Research, Southern Section, University of California.

Chambers, R. (1947). Financial Management. Sydney: The Law Book Co. of Australasia Pty Lid.

Chambers, R. (1949). 'Accounting and shifting price levels'. The Australian Accountant, 19 (September): 313-320.

Chambers, R. (1952a). 'Accounting and business finance'. The Australian Accountant, 22 (July): 213-230 and (August): 262-273. 
Chambers, R. (1952b). 'Accounting and inflation'. The Australian Accountant, 22 (January): 14-23.

Chambers, R. (1955a). 'Blueprint for a theory of accounting'. Accounting Research, 6 (January): 17-25.

Chambers, R. (1955b). The Function and Design of Company Anutal Reports. Sydney: The Law Book Co. of Australasia Pty Lid.

Chambers, R. (1956). 'Some observations on "Structure of Accounting Theory". The Accounting Review, 31 (October): 584-592.

Chambers, R. (1957a). 'Detail for a blueprint'. The Accounting Review, 32 (April): 206-215.

Chambers, R. (1957b). Accounting and Action. Sydney: The Law Book Co. of Australasia Pty Ltd.

Chambers, R. (1960). 'The conditions of research in accounting'. The Journal of Accountancy, 110 (December): 33-39.

Chambers, R. (1961). Towards a General Theory of Accounting. Australian Society of Accountants Annual Lecture, University of Adelaide.

Chambers, R. (1962). 'Changes in accounting theory' in Chambers, R. and Dean, G. (eds.), Chambers on Accounting: III, 33-49. New York: Garland Publishing, Inc., 1986.

Chambers, R. (1963a). 'USA, 1962 - some observations'. News Bulletin (of the Australian Association of University Teachers of Accounting), 3 (April): 3-6.

Chambers, R. (1963b). 'Why bother with postulates?' Journal of Accounting Research, I (Spring): 3-I5.

Chambers, R. (1963c). The Resolution of Some Paradoxes in Accouning. Vancouver, BC, Canada: Faculty of Commerce and Business Administration, University of British Columbia.

Chambers, R. (1964a). 'The Moonitz and Sprouse studies on postulates and principles'. The Australasian Association of University Teachers of Accounting: Papers Presented at the AAUTA: University of Sydney, August, 1962 and Australian National University, January, 1964: 34-54.

Chambers, R. (1964b). 'Conventions, doctrines and common sense'. The Accouttants' Journal (NZ), 42 (February): 182-187.

Chambers, R. (1965a). 'Edwards and Bell on business income'. The Accounting Review, 40 (October): 731-74I. Chambers, R. (1965b), 'The development of accounting theory' in Chambers, R., Goldberg, L. and Mathews, R. (eds.), The Accounting Frontier: In Honour of Sir Alexander Fizgerald: 18-35. Melbourne: F. W. Cheshire.

Chambers, R. (1965c). 'The price-level problem and some intellectual grooves'. Journal of Accounting Research 3 (Autumn): 242-252.

Chambers, R. (1965d). 'Measurement in accounting'. Journal of Accounting Research, 3 (Spring): 32-62.

Chambers, R. (1966a). 'Accounting and analytical methods: a review article'. Journal of Accounting Research, 4 (Spring): 101-118.

Chambers, R. (1966b). Accounting, Evaluation and Economic Behavior. Englewood Cliffs, NJ: Prentice-Hall, Inc.

Chambers, R. (1966c). 'A matter of principle'. The Accounting Review, 41 (July): 443-457.

Chambers, R. (1966d). 'A study of a price level study'. Abacus, 2 (December): 97-118.

Chambers, R. (1967a). 'The foundations of financial accounting' in Berkeley Symposium on the Foundations of Financial Accouning: 26-44. Schools of Business Administration, University of California, Berkeley.

Chambers, R. (1967b). 'Price variation accounting - an improved representation'. Joumal of Accounting Research,
5 (Autumn): 215-220.

Chambers, R. (1969a). 'Abacus'. The AAUTA News

Bullesin, 9 (July): 11-14.

Chambers, R. (1969b). Accounting. Finance and Management. Arthur Andersen \& Co.

Chambers, R. (1970). 'Second thoughts on continuously contemporary accounting'. Abacus, 6 (September): 39-55.

Chambers, R. (197/a). 'Income and capital: Fisher's legacy'. Journal of Accouning Research, 9 (Spring): 137-149.

Châmbers, R. (197/b). 'Value to the owner'. Abacus, 7 (June): 62-72.

Chambers, R. (1972a). 'Multiple column accounting - cui bono?' The Chartered Accountant in Australia, 42 (March): 4-8.

Chambers, R. (1972b). 'Measurement in current accounting practice: a critique'. The Accounting Review, 47 (July): 488-509.

Chambers, R. (1972c). 'Quo vado?' The Chartered Accountant in Australia, 43 (August): 13-15.

Chambers, R. (1973). Securities and Obscurities: A Case for Reform of the Law of Company Accounts. Melbourne: Gower Press Australia.

Chambers, R. (1974a). 'The development of the theory of continuously contemporary accounting' in Chambers, R., Accounting, Evaluation and Economic Behavior: v-xxvii. Houston, TX: Scholars Book Co.

Chambers, R. (1974b). 'Third thoughts'. Abacus, 10 (December): 129-137.

Chambers, R. (1975a). Accounting for Inflation: Methods and Problems. Department of Accounting, The University of Sydney.

Chambers, R. (1975b). Accounting for Inflation: Exposure Draft. Department of Accounting, The University of Sydney.

Chambers, R. (1976a). 'Accounting for changing prices' in Chambers, $R$. and Dean, G. (eds.), Chambers on Accounting: V, 269-277. New York: Garland Publishing, Inc., 1986.

Chambers, R. (1976b). 'The possibility of a normative accounting standard'. The Accounting Review, 51 (July): 646-652.

Chambers, R. (1976c). Current Cost Accounting - A Critique of the Sandilands Report. International Centre for Research in Accounting, University of Lancaster.

Chambers, R. (1976d). 'Continuously contemporary accounting: misunderstandings and misrepresentations'. Abacus, 12 (December): 137-151.

Chambers, R. [committee chairman] (1978a). Company Accounting Standards: Report of the Accounting Standards Review Committee. Government Printer, New South Wales.

Chambers, R. (1978b). 'The use and abuse of a notation: a history of an idea'. Abacus, 14 (December): 122-144.

Chambers, R. (1979). 'Canning's The Economics of Accountancy - after 50 years'. The Accounfing Review, 54 (October): 764-775.

Chambers, R. (1980). 'Groundwork for accounting standards or 30 reasons for CoCoA'. In Chambers, R. and Dean, G. (eds.), Chambers on Accounting: V, 373-399. New York: Garland Publishing Co., Inc., 1986.

Chambers, R. (1982). 'Edwards and Bell on income measurement in retrospect'. Abacus, 18 (June): I-39.

Chambers, R. (1983). 'Accounting for foreign business'. Abacus, 19 (June): 14-28.

Chambers, R. (1991). 'An academic apprenticeship' in Carnegie, G. and Wolnizer, P. (eds.), Accounting History Newsletter 1980-1989 and Accounting History 
1989-1994: A Tribute to Robert William Gibson: 10!-111. New York: Garland Publishing. Inc., 1996.

Chambers, R. (1993). 'Positive accounting theory and the P A cult', Abacus, 29 (March); I-26.

Chambers, R. (1995). An Accounting Thesaurus: 500 Years of Accounting. Oxford: Pergamon.

Chambers, R. (1998). 'Wanted: foundations of accounting measurement'. Abacus, 34 (March): 36-47.

Chambers, R. (2000). 'Early beginnings: introduction to Wisdom of Accounting'. Abacus, 36 (October): 313-320.

Chambers, R. and Dean, G. (1986/2000). Chambers on Accounting, 6 volumes. New York: Garland Publishing, Inc.

Chambers, R., Goldberg, L. and Mathews, R. (eds.) (1965). The Accounting Frontier: In Honour of Sir Alexander Fitzgerald. Melbourne: F. W. Cheshire.

Coase, R. (1938). 'Business organisation and the accountant'. The Accountant, 99 (1 October-17 December).

Copland, D. (1965). "Introduction" in Chambers, R., Goldberg, L. and Mathews, R. (eds.), The Accounting Frontier: In Honour of Sir Alexander Fitzgerald. Melbourne: F. W, Cheshire.

Cruse, R. (1967). Review of Accounting, Evaluation and Econonic Behavior. The Accounting Review, 42 (January): 207-208.

Davidson, S. (1984). "The origins of the Journal of Accounting Research'. In Dyckman, T. and Zeff, S., 'Two decades of the Journal of Accounting Research': 281-285. Journal of Accounting Research, Spring.

Dean, G. (2000). Editorial, Abacus, 36 (February): 1-3.

Dein, R. (1966). Review of Accounting, Evaluation and Economic Behavior. The Journal of Accountancy, 122 (October): 89-90.

Dixon, R. (1968). Review of Practising Accountants in Australia. The Accounting Review, 43 (July): 614-615.

Edgeloe, V. (1989). 'Commercial education provided by the University of Adelaide 1902-1954'. Unpublished paper.

Edwards, E. and Bell, P. (1961). The Theory and Measurement of Business Income. Berkeley: University of California Press.

Edwards, R. (1938). "The nature and measurement of income'. The Accountant, 99 (2 July-24 September).

Feltham, G. and Ohlson, J. (1995). "Valuation and clean surplus accounting'. Contemporary Accounting Research, 11 (Spring): 689-731

Finn, F. (1999). 'Vale to Reg Gynther'. Prepared for Accounting \& Finance, 17 December.

Fitzgerald, A. (1952). Current Accounting Trends. Sydney: Butterworth \& Co. (Australia) Ltd.

Fitzgerald, A. and Schumer, L. (1952). Classification in Accounting. Sydney: Butterworth \& Co. (Australia) Lid.

Gee, K and Peasnell, K. (1976). 'A pragmatic defence of replacement cost'. Accounting and Business Research, 6 (Autumn): 242-249.

Gibson, R. (1984). 'The role of Australian universities in developing and spreading accounting Ideas' in Fourth International Congress of the History of Accountancy: 231-260. Pisa: ETS Editrice.

Goldberg, L. (1939). A Philosophy of Accounting. Melbourne: Accountants Publishing Company Limited.

Goldberg, L. (1981). The Florescent Decade: Accounting Education in Australia 1945-1955. Accounting Association of Australia and New Zealand.

Goldberg, L. (1987). Dynamics of an Entity: The History of the Accounting Association of Australia and New Zealand. Accounting Association of Australia and New Zealand.

Grewal, B. and Barton, A. (2000). 'Russell Lloyd Mathews: an appreciation'. The Economic Record, 76 (December): 401-411.

Gynther, M. (1990). 'The Department of Commerce at the University of Queensland'. Accounting History, Vol. 2 (No. 1): 23-27.

Gynther, R. (1962). 'Accounting for price level changes - one general index or several specific indexes?' Accountancy, 73 (July): 560-564.

Gynther, R. (1966). Accounting for Price-Level Changes: Theory and Procedures. Oxford: Pergamon Press.

Gynther, R. (1967a). 'Accounting concepts and behavioral hypotheses'. The Accounting Review, 42 (April): 274-290. Gynther, R. (1967b). Practising Accountants in Australia: An Analytical Study. St. Lucia, Qld.: University of Queensland Press.

Gynther, R. (1969). 'Some "conceptualizing" on goodwill' The Accounting Review, 44 (April): 247-255.

Gynther, R. (1970), 'Capital maintenance, price changes, and profit determination'. The Accounting Review, 45 (October): 712-730.

Gynther, R. (197I). 'Accounting for price changes: some recent thinking, recommendations and practice'. The Chartered Accountant in Australia, 42 (December): 12-23.

Gynther, R. (1972). 'A Comment', letter to the editor. The Chartered Accountant in Australia, 42 (May): 40, 42.

Gynther, R. (1974). 'Why use general purchasing power?' Accounting and Business Research, 4 (Spring): 141-157.

Harcourt, G (1982). The Social Science Imperialists, London: Routledge \& Kegan Paul.

Hendriksen, E. (1961). Price-level Adjustments of Financial Statements - An Evaluation and Case Study of Two Public Utility Firms. Pullman: Washington State University Press.

Hendriksen, E. (1963). 'Purchasing power and replacement cost concepts - are they related?' The Accounting Review, 38 (April: 483-491).

Hendriksen, E. (1967). Review of Accounting. Evaluation and Economic Behavior. The Journal of Business, 40 (April): 211-213.

Karmel, P. and Barton, A. (2000). 'Dominant figure in accounting theory'. ANU Reporter, (31 March): 5.

Kerr, J, and Clift, R. (1989). 'Louis Goldberg - educator and scholar' in Kerr, J. and Clift, R. (eds.), Essays in Honour of Louis Goldberg: 1-15. Melboume: Department of Accounting and Business Law, University of Melbourne.

Littleton, A. (1953). Structure of Accounting Theory. American Accounting Association.

Littleton, A. (1956a), "Towards understanding accountancy'. The Australian Accountant, 26 (February): 81-84.

Littleton, A. (1956b). 'Choice among alternatives'. The Accounting Review, 31 (July): 363-370.

Mathews, R. (1948). 'Government accounts for social accounting'. The Australian Accountant, 18 (December): 437-449.

Mathews, R. (1952), 'New horizons in accounting: the application of accounting techniques to problems of social accounting'. The Australian Accountant, 22 (April): 105-115, (May): 141-157, and (June): 177-192.

Mathews, R. (1957). 'Government accounts and social accounting'. The Australian Accountant, 27 (January): 35-50.

Mathews. R. (1961), Militia Battalion at War. Melbourne: 58/59th Battalion Association.

Mathews, R. (1962). Accounting for Economists. Melbourne: F. W. Cheshire.

Mathews, R. (1964a). 'Unjversity Education for Accountancy". The Australasian Association of University 
Teachers of Accounting: Papers Presented at the AAUTA: Universiry of Sydney, August, 1962 and Australian National University, January, 1964: 23-28.

Mathews, R. (1964b). "Commercial education in the University of Adelaide: Part I - 1902 to 1949'. News Bulletin (of the Australasian Association of University Teachers of Accounting), 4 (April): 1-I1.

Mathews, R. (1964c). "Commercial education in the University of Adelaide: Part II - 1950 to 1964. News Bulletin (of the Australasian Association of University Teachers of Accounting), 4 (June): I-14.

Mathews, R. (1965a). 'Price-level changes and useless information'. Journal of Accounting Research, 3 (Spring): I33-155.

Mathews, R. (1965b). 'Educational reform and the accountancy profession - the Vatter and Martin Reports'. The Australasian Association of University Teachers of Accounting: Papers Presented at AAUTA Conference. The University of Melbourne, May 25/27: 3B-1 to 3B-18.

Mathews, R. (1967). 'The price-level controversy: a reply'. Journal of Accounting Research, 5 (Spring): 113-118.

Mathews, R. (1968). 'Price variation accounting - a rejoinder'. Journal of Accounting Research, 6 (Autumn): 284-285.

Mathews, R. (1971). The Accounting Framework. Melbourne: Cheshire.

Mathews, R. (1977). 'The shift to current values: The Mathews and Richardson Reports'. The Accountants' Journal, 56 (April): 85-92.

Mathews, R. (1980). 'The Mathews Report on business taxation: a reply'. The Economic Record, 56 (September): 261-269.

Mathews, R. (1982). 'Chambers and the development of accounting theory: a personal reminiscence'. Abacus, 18 (December): 175-178.

Mathews, R. and Grant J. (1958). Inflation and Company Finance. Sydney: The Law Book Co. of Australasia Pty Ltd.

McDonald, D. (1966). Review of Accounting, Evaluation and Economic Behavior. The Canadian Chartered Accountant, 89 (August): 78-79.

Moonitz, M. (1961). The Basic Postulates of Accounting. New York: American Institute of Certified Public Accountants.

Moonitz, M. (1982). 'Chambers at the American Institute of Certified Public Accountants'. Abacus, I 8 (December): 106-111.

Nelson, C. (1967), 'Discussion by Carł L. Nelson' in Berkeley Symposium on the Foundations of Financial Accounting: 50-54. Berkeley, CA: Schools of Business Administration, University of California, Berkeley.

Nelson, C. (1973). 'A priori research in accounting' in Dopuch, N. and Revsine, L. (eds.), Accounting Research 1960-1970: A Critical Evaluation: 3-19. Center for International Education and Research in Accounting, University of Illinois.

Nightingirl, D. (1956). Review of The Function and Design of Company Amnual Reports. Accounting Research, 7 (October): 399-400.

OhIson, J. (1995). 'Earnings, book values and dividends in equity valuation'. Contentporary Accounting Research, I1 (Spring): 661-687.

Parker, L. (1994). 'Impressions of a scholarly gentleman: Professor Louis Goldberg'. The Accounting Historians Jountal, 21 (December): 1-40.

Parker, R. and Harcourt, G. (1969). 'Introduction' in Parker, R. and Harcourt, G. (eds.), Readings in the Concept and Measurement of Income: 1-30. London: Cambridge University Press.
Prospectus 2000/Department of Commerce (2000). UQ Business School, University of Queensland.

Report of the Committee on the Future of Tertiary Education in Australia to the Australian Universities Commission (Martin Report) (1964). Tertiary Education in Australia. Canberra: Government Printer.

Report of Committee of Inquiry into Inflation and Taxation (Mathews Report) (1975). Inflation and Taxation. Canberra: Australian Government Publishing Service.

Report of the Review of the Accounting Discipline in Higher Education (Mathews Report) (1990). Accounting in Higher Education. Canberra: Australian Government Publishing Service.

Report of the Committee of Inquiry into Inflation Accounting (Richardson Report) (1976). Wellington, New Zealand: Government Printer.

Robbins, L. (1932). An Essay on the Nature and Significance of Economic Science. London: Macmillan.

Robinson, J. (1956). The Accumulation of Capital. London: Macmillan.

Sandilands Committee (1975). Inflation Accounting: Report of the Inflation Accounting Committee, F. E. P. Sandilands Esq, CBE, Chairman. London: Her Majesty's Stationery Office.

Schmidt, F. (1931). 'Is appreciation profit?' The Accounting Review, 6 (December): 289-293.

Solomons, D. (1966). Review of Accounting, Evaluation and Economic Behavior. Abacus, 2 (December): 205-209.

Staff of the Accounting Research Division (1963). Reporting the Financial Effects of Price-Level Changes, Accounting Research Study No. 6. New York: American Institute of Certified Public Accountants.

Stamp, E. (1972). 'R. J. Chambers: Quo vadis et cui bono?' The Chartered Accountant in Australia, 43 (August): $10-12$.

Stamp, E. (1983). 'Does the Chambers' evidence support the CoCoA system?' Accounting and Business Research, 13 (Spring): 119-127.

Swan, P. (1978). 'The Mathews Report on business taxation'. The Economic Record, 54 (April): 1-16.

Swan, P. (1980). 'The Mathews Report on business taxation: a rejoinder'. The Economic Record, 56 (September): 270-277.

Sweeney, H. (1936). Stabilized Accouting. New York: Harper \& Brothers.

Trow, D. and Zeff, S. (1976). 'Recent developments in financial reporting in New Zealand'. The Accountant's Magazine, 80 (September): 342-344.

Tweedie, D. and Whittington, G. (1984). The Debate on Inflation Accounting. Cambridge: Cambridge University Press.

Tweedie, D. and Whittington, G. (1997). 'The end of the current cost revolution' in Nobes, C. and Cooke, T. (eds.), The Development of Accounting in an International Context: 149-176. London: Routledge.

'The University of Adelaide' (1973). The Australian Accountant, 43 (August): $423-425$.

Vatter, W. (1964). Survey of Accountancy Education in Australia, sponsored by the Atrstralian Society of Accountants, The Institute of Chartered Accountants in Australia, The Australasian Institute of Cost Accountants [Melbourne].

von Mises, L. (1949). Human Action. London: William Hodge and Company, Limited.

Walker, R. (1968). Review of Practising Accountants in Australia. Abacus, 4 (August): 92-95.

Watts, R. and Zimmerman, J. (1979). "The demand for and supply of accounting theories: the market for excuses'. The Accounting Review, 54 (April): 273-305. 
Wells, M. (2000). 'Founding Abacus: frustration to fulfilment'. Abacus, 36 (October): 255-266.

Whittington, G. (1981). 'The British contribution to income theory' in Bromwich, M. and Hopwood, A. (eds.), Essays in British Accounting Research: 1-29. London: Pitman.

Whittington, G. (1994). 'The LSE triumvirate and its contribution to price change accounting' in Edwards, J. (ed.), Twentieth-Century Accounting Thinkers: 252-273. London: Routledge.

Wolnizer, P. (2000). 'Raymond John Chambers'. Abacus, 36 (February): 1-3.
Wright, F. (1966). Review of Accounting, Evaluation and Economic Behavior. The Australian Accountant, 36 (October): 535.

Yule, P. (2000). 'The Department of Commerce of The University of Queensland', draft version, September.

Zeff, S. (1997). 'The early years of the Association of University Teachers of Accounting: 1947-1959'. The Brisish Accounting Review, 29 (June, Special Issue): 3-39.

Zeff, S. (2000). 'John B. Canning: a view of his academic career'. Abacus, 36 (February): 4-39. 
Copyright of Accounting \& Business Research is the property of Croner.CCH Group Limited and its content may not be copied or emailed to multiple sites or posted to a listserv without the copyright holder's express written permission. However, users may print, download, or email articles for individual use. 